\title{
IMMOVABLE FOOD STORAGE FACILITIES, KNOWLEDGE, AND LANDSCAPE IN NON-SEDENTARY SOCIETIES: PERSPECTIVES FROM NORTHERN MICHIGAN
}

Meghan C.L. Howey and Kathryn Frederick

\section{DO NOT CITE IN ANY CONTEXT WITHOUT AUTHOR'S PERMISSION}

Meghan C.L. Howey, University of New Hampshire, Department of Anthropology, 73 Main

Street, 313 Huddleston Hall, Durham, NH 03824; meghan.howey@unh.edu

Kathryn Frederick, Michigan State University, Department of Anthropology, 655 Auditorium

Drive, East Lansing, MI 48824; hammon85@msu.edu 
Storage, "or the setting aside of material things (food, tools, water, seeds for plants) for some future use -- whether short or long term -- is a fact of economic and social life in all cultures, at all times and in all places" (Halperin 1994:167). While any number of materials can be stored, the storage of food is a particularly significant practice. Societies must respond to environmental and/or cultural variability that can lead to severe and unpredictable scarcity in vital resources, of which food is one of the most (Halstead and O'Shea 1989:2). Food storage is one key response to mitigating against scarcity and societies practice different forms of food storage given the specific stressors they face (Brenton 1988). Three main forms of food storage include: 1) physical storage, 2) biological storage as fat on one's body, and 3) social storage through exchange relationships (Morgan 2012:715; similar groupings iterated in Halstead and O'Shea 1989; Ingold 1983; Soffer 1989).

In anthropological and archaeological research, physical food storage was first understood as a response tied to the emergence of social stratification -- economic specialization produces food surplus, storage is intensified to accommodate and extend surplus, sedentism increases, and ultimately some members of society come to control more of the surplus than others, precipitating the classic shift defined by Sahlins (1972) from a Domestic Mode of Production to a public economy. This scenario has been studied in the rise of farming-based chiefdoms and states and has also been documented among complex hunter-gatherers constituted primarily of oceanic coastal-adapted hunter-fisher societies where predictable and abundant wild resources stand in for agricultural products (Keeley 1988:373-4; cf. Ames 1994, 2003; Arnold (ed.) 1996; Fitzhugh 2002; Grier et al. (eds.) 2006; Koyama and Thomas (eds.) 1981; Sakaguchi 2009; Testart 1982). 
With such linkages between physical food storage, sedentism, and increased (and eventually, permanent) inequality, if, and if so, why, when, and how egalitarian, relatively low density, mobile hunter-gatherer-fisher (and low-level horticulturalist) societies practiced physical food storage became a topic of debate in the 1980s (Binford 1980; Halstead and O'Shea 1989; Ingold 1983; Rowley-Conwy and Zvelebil 1989; Soffer 1989; Testart 1982). Some early research emphasized the importance of social storage based on the pooling of risk through social obligations to be "cashed in" in times of future resource scarcity in such societies (Cashdan 1985; Goland 1991; Jochim 1981; Spielmann 1983; O’Shea 1981; Wiessner 1982). These systems of social exchange appeared better suited to mobility than physical food storage. However, now classic studies by Ingold (1983) and Binford (1980) made it clear that mobile hunter-gatherers could also, and did, regularly practice physical food storage.

Scholarship on physical food storage in the adaptations of relatively low density, mobile hunter-gatherer-fisher (and low-level horticulturalist) societies has, accordingly, expanded (Cunningham 2011; Dunham 2000, 2009; Frink 2007; Kuijt 2009; Morgan 2012; O’Shea 1989a; Rowley-Conwy and Zvelebil 1989; Soffer 1989; Stopp 2002; Tushingham and Bettinger 2013; Whelan et al. 2013). This research has made it clear that physical food storage in such societies is not some kind of prelude to complexity but an "important practice in its own right with both practical and social meaning throughout prehistory" (Cunningham 2011:143). This ongoing research shows physical food storage practices are also dynamic and varied, and so can defy easy categorization.

Portable storage (e.g., pemmican) and caches appear especially widespread in egalitarian, non-sedentary societies and these practices tend to be grouped under the rubric small-scale storage, contrasted with large-scale storage involving advanced preservation techniques and 
immovable facilities (i.e., granaries) (Cunningham 2011: 137). However, portable storage and caching can occur in different ways and on vastly different scales. Non-sedentary huntergatherer-low-level horticulturalist societies can come to cache large quantities of food resources (Stopp 2002:314-5) and do so in immovable facilities (Simms 2008:227-8). We are interested in cases where physical food storage in mobile societies involves such practices typically categorized as large-scale storage. Specifically, we ask, what are the technological and landscape placement challenges mobile hunter-gatherer (and low-level horticulturalist) societies have to navigate when they use immovable food storage facilities? And following, what impact does navigating these challenges have on social, economic, and ideological processes?

We provide a case study of the use of immovable food storage facilities by mixed forager-fisher-horticulturalists in the northern Great Lakes region during the Late Precontact period (ca. AD 1100/1200 -1600). During this period, the region witnessed an intensification of extant subsistence practices (fishing and foraging) and a rise in maize horticulture in preferential climactic settings locally; these subsistence shifts resulted in increasing spatial circumscription (O'Shea 2003). Across the region, communities found themselves engaging in their annual mobility rounds within more spatially and socially restricted territories. With the (wild and cultivated) resource base of the region being both seasonally variable and unpredictable year-toyear, the reduction in the spatial range communities could exploit to harvest food resources heightened the risk of experiencing food scarcity. The need to both maximize and extend the uselife of local food abundances became critical.

Communities invested in physical food storage in immovable storage facilities in the form of cache pit (subterranean food storage) clusters dispersed from residential sites to respond to the novel mix of social and ecological stressors they faced in Late Precontact (Dunham 2000; 
Holman and Krist 2001; Holman and Lovis 2008; Howey 2015). Exploring cache pits in detail in one inland lake landscape, we examine the technological, social, and spatial challenges presented by relying on and constructing immovable food storage facilities here, and how, in answering these challenges, people, and their knowledge, became evermore committed to each other and to their landscapes, connections increasingly important to well-being in the context of Late Precontact.

\section{Immovable Food Storage Facility Challenges in Non-Sedentary Societies}

In any society, responses to unpredictability and potential food scarcity have to balance needs for long-term security and day-to-day operating efficiency (Halstead and O'Shea 1989:5). When physical food storage is used to extend food supply to help create security, it takes an investment of time and labor diverted from daily activities critical to efficiency (Morgan 2012: 717). In larger-scale societies there are structures in place for pooling labor without compromising daily operations, but such a diversion of time and labor in relatively low-density, egalitarian, non-sedentary societies carries the potential to impact efficiency (Trigger 1990). Groups have to find ways to accomplish daily subsistence tasks while also collecting and processing extra food for storage (Whelan et al. 2013). Such shifting of social and material resources to physical food storage can also diminish the capacity to pursue other scarcity mitigation strategies. When physical food storage is developed as an adaptive strategy in relatively low density, egalitarian, non-sedentary hunter-gatherer-low-level horticulturalist societies, there is pressing need for high rates of success to accommodate these opportunity costs. 
When non-sedentary societies rely on immovable facilities for their physical food storage practices, costs and risks are intensified. Fixed food storage facilities can require not just more time and labor than other forms of physical food storage, such as portable storage, but they present heightened chances for front-end costs to be completely wasted due to storage facility failure where stored food is not consumed (O'Shea 1989a; Tushingham and Bettinger 2013). With portable storage, foodstuffs travel with those who produced them (Stopp 2002). With immovable food storage facilities in mobile societies, cached food is fixed and so there are episodes of varied duration where stored foods are separate from the people who constructed and filled the facilities. A suite of factors can readily lead to immovable food storage facility failure. Non-sedentary societies must grapple with these challenges.

Immovable storage facilities can fail technologically. For immovable food storage facilities to serve any role in mediating scarcity, the technology of them must be sufficiently developed such that they actually preserve foodstuffs over time (Minc and Smith 1989:10). Immovable storage facilities, both above ground and subterranean, can fail structurally, breaking down/falling/collapsing and destroying contained food. Ubiquitous elements can cause contained food to rot - water, light, heat - making rot a constant threat to storage failure that must be minimized by the technological attributes of immovable food storage facilities in any setting.

Immovable food storage facilities can also fail due to what we categorize here as landscape placement issues. Immovable storage facilities can fail if they are not placed in locations where natural elements that promote rot, such as water and/or sun overexposure, are reduced. They can fail if they are placed inefficiently such that the effort required to store foodstuffs in them diminishes the return benefit of the stored food resources. Immovable storage facilities can fail if they are placed where outside, potentially hostile, communities can raid them 
and take their contents (DeBoer 1988). They can also fail if the mobile communities reliant on them are unable to return to them and access their contents (Morgan 2012; Tushingham and Bettinger 2013; Whelan et al. 2013).

When immovable facilities are used for caching in non-sedentary societies, the risks, costs, and commitments of food storage are manifest in these facilities. Immovable facilities a) have to be technically sound constructions and b) their positioning in the landscape has to be well-planned, including being located in areas where the chances of socio-natural elements increasing storage failure (water rot, sun overexposure, social raiding, etc.) are reduced, where locally available storable food stuffs can be placed in them, and where they can be reasonably accessed by the communities reliant on them (Howey 2015).

Myriad questions arise from these considerations. How do non-sedentary societies, composed, as they are, of spatially and temporally dispersed community members circulate the knowledge about constructing technologically adequate immovable food storage facilities? How do dispersed, relatively low-density communities coordinate the time and labor investment necessary for the construction and maintenance of immovable food storage facilities? How do groups place immovable storage facilities around constraints posed by ecological variability and socioeconomic mobility patterns? How do people strategically place their food storage facilities when landscapes are traversed by more than one group? We suggest immovable food storage facilities themselves can be used to bear of some of the answers to these questions.

\section{(Em)placed Facilities}

In mobile societies, the acquisition of accurate information about the social and ecological variability extant in traversed landscapes is critical to survival (Funk 2011; Lovis and 
Donahue 2011; Minc 1986). Mobile communities have to find ways to disseminate critical acquired knowledge about risks and opportunities, and the best means for responding to these, without relying only on face-to-face interaction. Socio-ecological knowledge has to be encoded, or stored, to flow across spatially and temporally dispersed community members (Whallon 2011:13). Ethnographically, we see this often entails verbal, social, and sacred systems of encoding (oral traditions, place-making, religious practices, kinship orders, gendered labor divisions) (for examples, see Basso 1996; Minc 1986; Wiessner 1982; Zedeno et al. 2009). Encoding can also be done using physical, spatially-embedded features and things like trail markers, waypoints, rock art, and portage marks are known to be vital information markers in mobile societies (for examples, see Aporta 2009; Darling 2009; Fowler 2009; Lovis and Donahue 2011; Norder 2003).

When mobile societies incorporate immovable food storage facilities into their cultural systems, these spatially-embedded features likewise serve to encode socio-ecological information critical to survival (Howey 2015). The material constructions that comprise fixed storage facilities hold record of the technique, resources, labor, time, and spatial placement considerations made in producing them. Given immovable food storage facilities are, by their very nature, designed to extend (themselves and, in turn, their contents) beyond the immediacy of the physical reshaping of raw materials into them, people remember and are brought back into encounter with these material features (Hendon 2000). The fabrication cycle of an immovable food storage facility is not complete after initial construction but includes subsequent phases of presence and use (sensu Munn 1977).

In these extended phases of immovable food storage facilities' fabrication cycle, members of non-sedentary societies moving through their annual rounds variously come to 
maintain, use, and reuse these features which are the direct result of the successful navigation of technological and landscape placement challenges of using immovable food storage in the context in which they are situated. Through people's repeated, tangible experiences with immovable food storage facilities, the critical socioecological knowledge about successful physical food storage encoded in these features is encountered and gets transmitted across spatially and temporally dispersed communities.

The decision to physically store food in spatially-fixed facilities by mobile societies also carries implications for connectedness to place. Immovable food storage facilities, as just discussed, are features built in set, specific places with the intent they will be remembered and returned to within mobility rounds (Binford 1980; Dunham 2000; Frederick 2011). Immovable storage facilities also require some level of maintenance, monitoring, and in some cases, even active safeguarding, to actually preserve the foodstuffs contained within them. These facts further draw mobile communities reliant on these facilities into deeper connections not just to the facilities themselves (and the information they encode) but also to the particular places in which these facilities are fixed.

We suggest it is productive to understand immovable food storage facilities as emplaced features, by which we mean, their placement in the landscape is the result of, but also subsequently the producer of, socioecological knowledge and relationships. The term emplacement reflects the dialectic of landscape, of people inhabiting and being inhabited by it (Basso 1996:102). Emplacement is a term increasingly used in anthropology to capture the fact that places entail physical features as well as the relationships people have with those features (and these can last well beyond any physical experience of these features, as is often observed in 
contemporary cases of displacement and migration; Stewart and Strathern 2005:214; see also Chu 2006; Gray 2011; Myers 2013).

Immovable storage facilities extend beyond their initial construction and they become woven into a communities' social fabric (Simms 2008:227). Such facilities are one of the ways mobile societies write, and then also experience, their enduring presence on their surroundings (Low and Lawrence-Zúñiga 2003: 13). As emplaced features, immovable storage facilities impact the way people traverse space, including their decision making about the physical contingencies of movement, their negotiations about the social contingencies of movement, and the meanings they interpret from their interaction with fixed storage facilities and the communities they intersect with at these places (Erickson 2009: 207).

\section{Immovable Food Storage Facilities in the Northern Great Lakes}

In the northern Great Lakes region, relatively low density, egalitarian, non-sedentary hunter-gatherer-fisher and low-level horticulturalist societies used physical food storage in immovable facilities to circumvent risks posed by socioecological variability (see Figure 1 for a general location of the northern Great Lakes region). Today, remnant depressions from cache

pits, fixed subterranean food storage facilities, are extremely abundant archaeological features in the northern Great Lakes. Historic Anishinaabeg groups continued to construct cache pits to some degree through the early 1900s, providing, then, a comparative ethnohistoric record of cache pits in active use (Brown 1917; Densmore 1929; Kinietz 1947; Tanner 1940 [1830]). The archaeological and ethnohistoric records of cache pit food storage were produced by the 
successful navigation of the technological and landscape placement challenges posed by the reliance on immovable food storage as a scarcity mitigation strategy in a mobile context.

As archaeological features, cache pits are circular, with diameters ranging from 1 to 2 meters and current surface depths between .3 to .6 meters. Ethnohistoric accounts indicate cache pits in active use were subterranean $u$-shaped features, ranging from 1 to 2 meters wide and deep, lined with birch bark, filled with multiple foodstuffs in containers with grass-type fill in between, and capped with mounded dirt. Frances Densmore (1929:40) during her work with Ojibwe communities in Minnesota, Wisconsin, and Ontario from 1907 - 1925 notes "a food cache was usually about 6 feet deep and was lined with birch bark. The rice and sugar were in makuks, and after they were in place the spaces between them were filled with hay. When the pit was nearly filled a covering of birch bark or hay was added. Beams of wood were laid across and the whole was covered with a mound of earth.” An early Euro-American settler, Mr. Richard Dart, in Wisconsin in 1841 observed caching by local tribal communities, noting "when plentiful, they dried fish in the sun till they were dry as powder, then put them in big puekawa sacks. The squaws also picked up bushels of acorns. In deep holes, below frost-line, they would bury their fish and acorns together, twenty bushels or so in a place and cover them over with a mound of earth" (Brown 1917: 31-32).

Cache pit archaeological features almost always occur in clusters which typically range from 10 to 25 pit depressions (Dunham 2000; Dustin 1966; Hambacher and Holman 1995; Schneider 1942; Schumacher 1918). However, clusters can have higher numbers. For instance, in northern Wisconsin, a cluster of 50 visible pits was recorded on Green Lake (the Dakin Creek Cache; Brown 1917:13) and a series of 75 pits was found in the Door Peninsula (Duchateau Point Caches; Shumacher 1918: 130). A group of 100+ pits was recorded by Greenman (1926) at 
the Missaukee Earthworks site (20MA11-12) in central Michigan and 93 were found associated with the Porter Creek site (20MN100) near Lake Michigan (Hambacher and Holman 1995:50).

Archaeological cache pit cluster locations also vary but they tend to be found in three common positions: a) in the immediate proximity of occupation sites in distinct spatial clusters on different topographic positions around the site b) clustered in the vicinity of occupation sites; and c) isolated from any occupation sites; some of these pits in removed locations occur at notable landmarks, like confluences of rivers and lakes (Dunham 2000; Hambacher and Holman 1995; Holman and Krist 2001). Cache pits, despite being such common archaeological features, have been the subject of limited research in large part because, when excavated, cache pits have not produced many, or even any, material artifacts (see Dunham 2000; Hambacher 1992; Hambacher and Holman 1995; Hinsdale 1931; O’Shea 1989b; Schneider 1942; Schumacher 1918). These results are not so unexpected for storage features in general. As Morgan (2012:716) notes, the "likelihood that stored food items will be found in archaeological features is low, partly due to taphonomic issues but mainly because a storer's intent is to re-access and eat stored food."

While the lack of materials in cache pits can be disappointing, we emphasize here that cache pits themselves are repositories of significant data, including evidence of the information they encoded about the technological and landscape placement challenges of relying on immovable storage facilities. Ethnohistoric accounts point to the import of these very considerations in cache pit construction in the region. In his narratives, John Tanner (a captive who ended up living with the Ojibwe), references making "sunjegwun" (cache pits) numerous times. In one narrative scene, Tanner laments having to construct a sunjegwun above ground from logs because the ground is too swampy to create the sunjegwun in the "usual manner of 
burying," which he identifies as preferable for keeping items both fresh and safe (Tanner 1940[1830]:35). Densmore (1929:40), again, notes "it was the custom to store food obtained during the summer in caches or pits dug near the village. The food kept perfectly, the pits were never disturbed, and this method of storage was safe and practical." In both accounts, the freshness and the safety of the stored food are particularly emphasized.

Cache pits appear from these historic accounts as purposefully, and well, designed storage features that answered key technological and landscape placement failure risks of immovable storage facilities, including rot and outside disturbance. Below, we turn to a case study from the period where the investment in food storage in immovable facilities fluoresced in the Great Lakes region, the Late Precontact period, to examine these patterns and processes further and to understand how they materialize in an archaeological context.

\section{Cache Pits in the Context of Late Precontact}

While there is evidence for some physical food storage in earlier time periods (see Bettarel and Smith 1973; Hambacher 1992), the Late Precontact period (ca. AD 1100/1200 1600) was marked by a notable rise in physical food storage realized through the construction and use of immovable cache pit clusters (Dunham 2000; Holman and Krist 2001). The rise of food storage in cache pit clusters dispersed in various ways from residential occupation was a strategic response to the distinct social and ecological stressors of Late Precontact.

Prior to the Late Precontact (ca. AD 1000/1100 to 1600) period, communities throughout the northern Great Lakes had practiced a broad spectrum strategy of foraging in which groups could move easily between resource zones on the shorelines of the Great Lakes, inland mixed deciduous and coniferous forests, lakes, wetlands, and rivers for millennia (Howey 2012). After 
ca. AD 1000/1100, more efficient production and consumption of food resources, including cultivated and wild, brought the first notable changes to this system. Along the coasts of the northern Great Lakes, fishing practices intensified and specialized on seasonal spawns and these activities assumed new importance (Cleland 1982). Inland from the coasts, foraging of locally available resources, including acorns and wild berries, also intensified (Dunham 2009). Finally, maize cultivation also became a more prominent part of local subsistence practices in the northern Great Lakes during this period (Crawford et al. 1997; Katzenberg et al. 1995; Martin 2008; O’Shea 2003; Raviele 2010).

The harsh and unpredictable climate of the northern Great Lakes meant that maize cultivation was always marked by a high risk of failure, risk that was somewhat mitigated by lake-effect along the coasts of Lake Michigan and Huron that extended the growing season (Figure 1). Accordingly, the scale of maize cultivation and the importance of maize in local economies varied across the region, largely in ways aligned with lake-effect climactic amelioration (Dunham 2009; Hart and Lovis 2013; Holman and Lovis 2008; O'Gorman 2007; O'Gorman and Lovis 2006; O’Shea 2003). As maize cultivation spread among hunter-gathererfisher communities living along the coasts of the northern Great Lakes, domesticated food production became one element in the mixed economy of these non-sedentary societies and, while significant in many ways, it never formed the core of the subsistence economy (O'Shea 1989a:67).

Maize cultivation and intensified fishing both benefited from a growing focus on Great Lakes shoreline and coastal settlements. Spending more time within annual mobility rounds on the coasts improved prospects for successful maize horticulture in lake-effect settings within the region's highly variable climate (O'Shea 2003) and allowed groups to secure access to key fall- 
and spring-spawning fishing locations (Holman and Lovis 2008). Groups living inland found the geographic circuits in which they could carry out their annual mobility round reduced by the more intensive local interactions and restricted ranges of movement along the coasts, having, then, to operate in what Holman and Krist (2001:19) have termed more restricted "seasonal districts".

Together, these subsistence shifts precipitated behavioral shifts including the "restructuring of patterns of settlement, territoriality, subsistence scheduling, and social alliance" (O’Shea 2003:6). During Late Precontact, the northern Great Lakes saw an increase in community size, the emergence of territorial systems with less permeable boundaries, the formalization of decision making, and the development of corporate groups (Cleland 1982, 1992; Holman and Lovis 2008; Howey 2012; O’Shea and Milner 2002). As communities found themselves, for the first time, engaging in seasonal resource procurement activities within spatially and socially restricted territories, the need to maximize local abundances became critical. The strategic use of dispersed cache pit storage became an essential buffer against starvation, an indispensable tool of survival (Holman and Lovis 2008:289).

While holding adaptive benefits of mitigating against scarcity, the investment in physical food storage in immovable storage facilities during Late Precontact also came with costs and risks. Groups had to accommodate non-routine time and labor costs of storage into already busy annual rounds -- in scheduling and conducting resource harvesting, in constructing cache pit facilities that successfully preserved foods, in maintaining these, in protecting them from unauthorized outside use, in arranging their mobility rounds to access them, and in postprocessing resources retrieved storage pits. If cache pits failed, the investment of time and labor (at the expense of other activities) that went into food storage would be wasted. In an already 
restricted and unpredictable setting, the waste of both time and nutritional product invested in storage would place a heavy burden on those experiencing cache failure.

During Late Precontact, groups had to ensure they successfully navigated technological and landscape placement challenges when they constructed their immovable cache pit food storage clusters, that this knowledge about successful food storage was embedded in these facilities, and that it was transmitted across communities. We look at these needs more closely in one inland lake landscape with a significant archaeological record of cache pit features. We especially consider how these immovable food storage features were fabricated, the work required in their construction, the forethought necessary in organizing both their construction and securing the food to be stored in them, and the decisions behind their specific placement on the landscape, including their relation to habitation sites and natural features.

\section{Technology and Landscape Placement in the Cache Pits of Douglas and Burt Lake, Northern Michigan}

Douglas Lake is located in the northern tip of the Lower Peninsula of Michigan, roughly $25 \mathrm{~km}$ south of the Mackinac Straits, where Lake Michigan and Lake Huron meet (Figure 2). Douglas Lake drains into the topographically lower and larger Burt Lake three kilometers south. Burt Lake is within the Inland Waterway, a series of lakes, rivers, and streams that creates an inland route between Lakes Michigan and Huron, providing an alternate route to the oftdangerous passage through the Mackinac Straits (Figure 2; Lovis 1976:366). The use of the Inland Waterway to travel between Lake Michigan and Huron is well-documented historically by Native Americans and European trappers (Blackbird 1887). 
The physiography of this area is the result of a complex history of Wisconsinan glacial advances and retreats and consists of glaciated moraines, outwash plains, drumlins, kames, and kettle lakes (Albert 1995; Francis 2001; Pearsall et al. 1995). Before clearing by Europeans drastically altered land cover, well-drained glacial features supported beech-maple-hemlock forest (a type of northern hardwood forest) while the more poorly drained outwash plains and moraines supported northern white cedar forested wetlands (Albert and Comer 2008:78). Douglas Lake abuts a major low-level outwash plain, the Pellston Plain, which forms one of the most climatically variable and harsh areas in the Lower Peninsula of Michigan, characterized by a short growing season, heavy snowfalls, and significant diurnal temperature fluctuations (Albert 1995).

Cache pits along these inland lakes were first documented on University of Michigan Biological Station (UMBS) property during a short reconnaissance along Burt Lake (Albert and Minc 1987). The University of Michigan Biological Station (UMBS) preserves 10,000 acres along Douglas and Burt Lakes, including several kilometers of shoreline, providing a unique opportunity to find relatively undisturbed archaeological sites on inland lakes which often host substantial recreational development. Follow-up research began in 2007 and 67 clusters of cache pits have now been found through walk-over survey conducted within a two kilometer buffer of Douglas and Burt Lake across UMBS property (Figure 3; note, pit clusters are all separated by at least 75 meters so overlaps are due to map scale). To contextualize these features, we have crosssectioned pits, performed shovel-test survey around pits, and located and excavated occupation sites in the vicinity of pits. 


\section{Precontact Occupation Trajectory on Douglas and Burt Lake}

Archaeological findings from our work indicate regular precontact activity around Douglas and Burt Lake began during the early Late Woodland period (ca. AD 600 - 1000), intensified between AD 1000 and 1200, and remained pronounced during Late Precontact (ca. 1000/1100 - 1600). Three occupation sites, two on Douglas Lake, and one on Burt Lake, have been excavated, and help to illuminate this occupation trajectory.

Site 20CN61 on a promontory along Douglas Lake, known colloquially as Grapevine Point, covered an area of approximately 15 x $20 \mathrm{~m}$ (Figure 3 and 4). Cultural materials as well as two AMS dates from the site show it was an early Late Woodland site (1310 $\pm 40 \mathrm{BP}$ with one

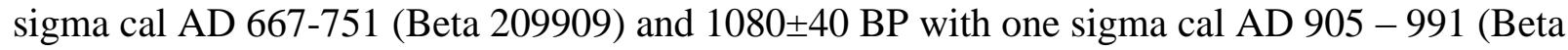

262447)). ${ }^{\mathrm{i}}$ The site produced no evidence of long-term habitation; no features, little fire cracked rock (FCR), and sparse calcined bone. Lithics include no primary flakes or cores and are predominantly formal tools of non-local cherts. Faunal remains, preserved well due to the wetness of the site, suggest that this was a resource extraction site with primary processing of deer and spring-spawning fish, notably perch and pike (see Howey and Parker 2008 for more on 20CN61).

Site 20CN63 is also on Grapevine Point but it covers a much larger area than 20CN61, with cultural material found in a $60 \times 40 \mathrm{~m}$ area (Figure 3 and 4). The site produced some early Late Woodland cultural materials and one secure early Late Woodland AMS date of 1214 $\pm 36 \mathrm{BP}$ one sigma cal AD 734 - 858 (AA86586). The majority of materials and radiometric dating indicate, however, that 20CN63 saw its primary occupation during the Late Precontact period

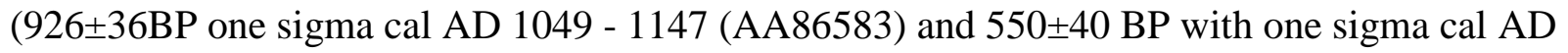
1324 - 1412 (Beta 209910)). Excavations found numerous cultural features and dense FCR, 
suggesting substantial residential habitation. Four large burned posts in a tight square were found, suggesting the presence of a central support for a large structure. Lithic materials are predominantly local glacial tills and include many cortex flakes and cores, indicating on-site production. The most common macrobotanical remain recovered was acorn; several possible nutting stones were also recovered. Maize was recovered, but only in very small quantities. Faunal remains come from a wide range of locally available terrestrial and aquatic animal resources, including bear, deer, turtle, beaver, and an intensive use of multiple fish species from the lake. Several burned sumac seeds have also been recovered (and no unburned or modern ones). Sumac is a strong indicator of disturbed and open habitat, which is what one would expect around a long occupied dwelling where most trees had been cleared (see Howey and Parker 2008 for more on 20CN63).

Site 20CN52 is located on a low terrace at the confluence of Carp Creek (which drains from Douglas Lake) and Burt Lake (Figure 3). The most significant find at this site was a large midden, a feature built up by repeated trash deposit episodes. Material highlights from inside the midden include a broken part of a large grinding stone, numerous dump piles of cooking hearth remains (with dense charcoal and calcined bone), and several decorated (broken) pipes. The presence of this true midden built up over years speaks to long-term, repeated occupation of this site. Charcoal from this midden dated to $950 \pm 40$ BP with one sigma cal AD 1037 - 1137 (Beta 26244). The ceramic assemblage fits this time period (with large amounts of Bois Blanc ware) but also includes many diagnostic sherds of later Late Precontact styles (Juntunen and Traverse Wares; for more on wares, see Hambacher 1992; Holman 1978; Milner 1998).

This, albeit brief, discussion of the excavations at these sites illustrates these inland lakes experienced an intensification of local occupation after ca. AD 1000. At the two sites dating 
predominantly after this time, $20 \mathrm{CN} 63$ and $20 \mathrm{CN} 52$, we found evidence of larger-scale, longerterm occupation that involved a range of activities across residential life (not just targeted resource procurement, as at 20CN61). At 20CN63, we also saw this longer residential occupation during Late Precontact included on-site processing and production activities emphasizing local raw materials and food resources. The rise of cache pit clusters formed another key aspect of the more intense use of this local landscape after ca. AD 1000/1100.

As indicated above, cache pits become common after this time across the northern Great Lakes; cache pit archaeological features overwhelmingly date to ca. AD 1000- 1600 based on associated ceramics (Dunham 2000: 229). Extant evidence from the cache pits on Douglas and Burt Lakes aligns with this regional fact. An AMS date of residue on a ceramic sherd found in a buried cache pit was 500 $\pm 40 \mathrm{BP}$ with a one sigma cal AD 1399-1431 (Beta 262448). Another ceramic sherd recovered in a different cache pit excavation has a strong collar, a feature characteristic almost exclusively on Late Precontact vessels. Additionally, systematic shovel testing has been conducted around five clusters of cache pits and has associated clusters of pits with $20 \mathrm{CN} 63$ and 20CN52 (more on this at 20CN63 below).

This trajectory of occupation, including the major investment in food storage pits locally, reflects communities occupying this inland lake landscape were involved in the broader nexuses of the regional shifts to an increasingly restricted (both spatially and seasonally) fisher-foragerhorticulturalist subsistence system as described above (Holman and Krist 2001; Holman and Lovis 2008; O’Shea 2003). As was occurring regionally during Late Precontact, communities occupying this interior landscape, inland from the coasts of the Great Lakes, had to carry out their annual rounds in more restricted seasonal districts and increased their focus on seasonal abundances of locally available wild foods amenable to storage. 
While certainly reflective of broader regional trends, the need to maximize seasonal abundances of locally storable resources was likely even more heightened in this particular inland lake landscape because, as mentioned above, Douglas Lake sits in one of the single most climactically harsh and unpredictable settings in the Lower Peninsula. This locale formed a place where successful food storage was, then, a particularly sensitive and critical issue.

We examine in turn a) the spatial distribution and b) the building of cache pits on Douglas and Burt Lake. We assess how communities navigated both technological and landscape placement challenges to reduce the chances these immovable food storage facilities, so critical to well-being, would fail. We argue that during the total fabrication cycle of cache pits, when people built, maintained, and used these fixed storage facilities, knowledge about reliable food storage in this local landscape was encoded in the materiality and spatial positioning of these features and through repeated encounters, this knowledge was transmitted across spatially and temporally dispersed groups, sustaining, then, a reliable system of food storage for scarcity mitigation.

\section{Spatial Distribution of Cache Pit Clusters}

The clusters of cache pits may appear at first glance to be spread everywhere (Figure 3). However, some consideration of their distribution shows communities placed clusters of cache pits across this inland lake landscape systematically in ways that increased the chances that these immovable facilities would be successful. They placed pits in ways that helped ensure the food stored within them would be protected from rot, where local foodstuffs could be placed in them with reasonable efficiency, and where the varied communities reliant on them in their annual 
rounds would be able to access them (and where those who were not supposed to access them would not).

Drainage. We worked with the National Cooperative Soil Survey SSURGO database to investigate soil associations of cache pit clusters. We calculated the area we have surveyed todate around the shores of Douglas and Burt Lake for cache pits (66050100 square meters) and computed on what soil type each cache pit cluster is located as well as how much of the survey area is composed of those soil series (Table 1). A remarkable $88 \%$ of cache pit clusters (59/67) occurred on Rubicon series soils. The Rubicon series "consists of very deep, excessively drained soils formed in sandy deposits on disintegration, ground, end and kame moraines, lake plains, outwash plains, stream terraces, beach ridges, and sand dunes. Saturated hydraulic conductivity is high or very high" (Soil Survey Staff 2010). High saturated hydraulic conductivity indicates water will move quickly through these highly permeable sands.

As indicated above, rot is a constant pressing technological challenge that must be navigated in the construction of successful fixed food storage facilities. Water saturation is one of the easiest ways to root food. Rubicon soils reduce the risk of saturation and subsequent rot of stored materials in the wet environment of northern Michigan. While $88 \%$ of the cache pit clusters are on this series, the Rubicon series composes, in contrast, $29.3 \%$ of the survey area, suggesting a strong, targeted preference for these soils for cache pit placement (Table 1). Also, no documented habitation sites occur on Rubicon soils. The patterns strongly suggest cache pits were purposefully located on these soils that provided excessive drainage. The inverse also seems apparent; no cache pit clusters were placed on poorly drained soil series and only 3 clusters of cache pits (4.5\% of known clusters) were even placed on moderately well drained 
soils, the rest, if not on the Rubicon excessively drained soils were on other well drained soil series (Table 1). Moreover, the moderately well drained Cheboygan series composes $11.8 \%$ of the survey area but only 1 cache pit cluster was built on this soil (1.5\% of known clusters) (Table 2).

This strong patterning of cache pits with well-drained soil series aligns with findings from some of our previous, complementary work on the cache pits here (Howey 2015). In this, we examined the distribution of these same cache pit clusters in relation to the area's Compound Topographic Index (CTI; Howey 2015). In short, CTI is a topographically derived measure that provides a robust index of water accumulation in soils. We found cache pit clusters were statistically significantly located on better drained areas than a random distribution of points in the study area (Howey 2015: 93).

Land Cover. Further support of the mindful placement of cache pits in locales that would have helped contribute to storage success lies in the distribution of cache pit clusters on different types of land cover. Obviously, contemporary land cover is not the same as the land cover that would have been extent during the Late Precontact period when cache pits were used. For a better estimate of the land cover at the time cache pits were in active use, we used the Biophysical Settings layer created by LANDFIRE (http://www.landfire.gov/). This geospatial layer provides an estimate of the vegetation that may have been dominant on the landscape prior to Euro-American settlement based on both the current biophysical environment and an approximation of the historical disturbance regime.

We computed on what land cover type each cache pit cluster is located. Cache pits occurred on three main categories of pre-Euro-American land cover types: Laurentian-Acadian 
Northern Hardwood forest (maple-birch-beech), Mixed Laurentian-Acadian Hardwood-Conifer forest (including both pine-oak and beech-maple-hemlock), and Conifer forest (including both spruce-fir and pine-hemlock). We calculated the amount of area covered in our study area by these three grouped categories of land cover and compared that with the number of cache pit clusters located on those categories. Cache pits are overrepresented on Laurentian-Acadian Northern Hardwoods and Mixed Laurentian-Acadian Northern Hardwood-Conifer forest land cover types (and neutral on Conifer forests). Taken together, the two land cover groups with Northern Hardwoods make up $58.5 \%$ of the study area but $89.55 \%$ of known cache pit clusters are located on these land cover types (Table 2).

Laurentian-Acadian Northern Hardwood forests would have hosted a plethora of potentially storable food resources. With maple a dominant tree type, these forests would have offered abundant sugar maple trees which can be sugared when their sap flows in early spring. Note, we have no direct evidence of maple sugaring (see Holman 1984 on the elusive archaeological signature of maple sugaring) but maple sugar was recorded ethnohistorically as a valued and stored product in the region. Maple-birch-beech forests support a fairly diverse groundlayer, including wild berries, particularly along sandier glacial features (Albert and Comer 2008). Berries, whose harvest seasons occur in late spring through summer, are likewise amenable to storage and were recorded in regional ethnohistoric accounts of caching (Densmore 1929). Red oak (Quercus rubra) also occurs in the canopies of these maple-birch-beech forests and are co-dominant in the pine-oak subtype of the area's Mixed Laurentian-Acadian Northern Hardwood-Conifer forest. Oak would provide acorns, a highly storable resource documented as important prehistorically and historically in the region, in early fall (masting typically in September/October) (Dunham 2009). 
Beyond floral resources, an array of game would have also been found across the area's land cover types and Northern Hardwoods may have presented local communities certain preferential animal compositions for storage, like bear (whose fat is highly storable and recorded as stored ethnohistorically) coming for the berries in the ground covering of these forests. Also, it is important to consider the preference for Northern Hardwood bearing land cover may be a reflection of knowledge about other benefits for cache pit storage technology beyond the food resources themselves, including things like sunlight or snow regimes more suitable for storage pit functioning than in Conifer forests, and certainly, such properties deserve further study. What our assessment of cache pit distribution on pre-Euro-American land cover does show is that people situated cache pits in ways that answered the landscape placement challenge of needing immovable facilities in locales where people could efficiently get locally available, storable food resources into them.

Landforms and Living Sites. As mentioned above, the physiography of the Douglas and Burt Lake landscape is the result of complex glacial history, which produced a variety of major and minor landforms around the lakes with different climatic and environmental profiles (Pearsall et al. 1995). Investigations on Grapevine Point, a promontory on Douglas Lake, illuminate the presence of interrelationships between landforms, living sites, and cache pit clusters. The area of Grapevine Point consists of three landforms in contact, a broad Low Terrace along the shoreline of Douglas Lake surrounded by a High Terrace and an even higher High Outwash (Figure 4). Both of these elevated landforms host Rubicon sands and had LaurentianAcadian Northern Hardwood forest before European settlement. 
As discussed above, there are two sites on the Low Terrace -- 20CN63, a (mostly) Late Precontact site and 20CN61, an early Late Woodland site. Clusters of cache pits occur on the two higher landforms with Rubicon sands. We documented one cluster of 20 visible cache pits on the High Terrace and two cache pit clusters, with 10 - 15 visible pits each, on the High Outwash (Figure 4). We cross-sectioned two pits on the High Terrace and one on High Outwash. Soil samples from distinct non-disturbed strata in each pit and a control sterile sample taken outside each pit were each floated, and the light fraction was examined for macrobotanical remains associated with the pits. Light fractions from all three pits produced limited floral materials, but what is present is interesting (Table 3).

Diverse carbonized wood remains were found inside the pits. Each had a mix of at least five Northern Hardwood forest tree species from maple, birch, beech, red oak, willow, American elm, ash, and hop hornbeam (Table 3), the diversity suggesting human selection rather than natural forest processes (Parker, personal communication, 2009). One of the sterile controls produced no wood, while the other two did produce wood remains, but only from one species (maple and ash respectively; Table 3). These patterns, as well as the fact that no edible floral remains were recovered in any of the sterile controls, bolster the interpretation that the rest of the plant contents recovered in internal cache pit light fraction botanical remains are from the cultural use of these pits (Table 3).

The two cache pits from the cluster on the High Terrace produced carbonized hazelnut and acorn nutshell as well as raspberry/blackberry and sumac seeds, all edible and storable food items (Parker, personal communication, 2009; Table 3). The cache pit on the higher elevation landform, High Outwash, produced no nuts or seeds, but we did recover a small calcined bone (>.01 grams) and one sherd (0.18 grams) from inside the pit. This bone was too small to even be 
coarsely identified but both land and lake here would have presented storable food resources and indeed a range of terrestrial fauna and spawning fish remains were recovered at the domestic sites on the Low Terrace. While far from conclusive, the presence of plant remains in pits on the High Terrace, their absence on the High Outwash but presence of a faunal remain, raises the possibility local inhabitants placed cache pits on multiple landforms to use differential properties of landforms to advance distinct food storage functions.

We conducted shovel test survey around the High Terrace cache pits to determine if and how these pits were associated with the living sites on the Low Terrace (for shovel test survey details, see Howey and Parker 2008). ${ }^{\text {ii }}$ Very few shovel tests produced artifacts, indicating limited activity around the cache pits. All positive tests ran linearly in a northeasterly direction towards the Late Precontact site 20CN63 and none in the direction of the early Late Woodland site $20 \mathrm{CN} 61$. We interpret these finds as reflecting a path of use from 20CN63 to and from the cache pits (Howey and Parker 2008).

The fact that the cache pits appear connected to the Late Precontact occupation on Grapevine Point accords with site excavation data outlined above. This later occupation was more substantial than the early Late Woodland occupation (at 20CN61), involving a range of residential activities. The site also showed a wider array of local plant and animal resource use, including acorn processing, which, discussed above, was a locally available resource highly amenable to storage and evidenced as stored in some of these associated cache pits.

The interrelationships evident here between cache pits, living sites, and landforms further demonstrates how people constructed pits in ways that answered varied aspects of both technological and landscape placement challenges presented by immovable food storage facilities in non-sedentary societies. These cache pits were located a) where local resources 
amenable to storage were available; b) where these could be processed and placed in storage pits; c) where surrounding landforms offered physiographic settings for storage technology to succeed; and d) where the local inhabitants who did the work to fill cache pits could access them and their contents.

Large Cache Pit Cluster Isolation. There are two large outlier clusters of cache pits in the 67 clusters found to-date; one at Pine Point and one at the Gorge (Figure 3). Some of the key landscape placement challenges of immovable storage facilities in mobile societies we noted above are the need to make sure the right people access stored resources and the wrong people do not. Looking at these two outliers in more detail, we see these were designed as distinct types of cache pit facilities serving different compositions of communities traversing the regional landscape.

The cluster on Pine Point, a promontory on the northeast shore of Douglas Lake, has over 60 visible, large pits. Shovel test survey was conducted on the land in the general vicinity of this large pit group prime for occupation (300 x $400 \mathrm{~m}$ grid, $10 \mathrm{~m}$ intervals, ca. 1200 tests). Only four tests were positive for cultural materials; this large store appears to have been removed from the vicinity of residential occupation.

Pine Point is not a particularly distinct landmark, nor does it occur at the confluence of any natural features. Isolated cache pit clusters in the northern Great Lakes have often been observed to have these aspects, suggesting strategic placement for access by multiple groups during resource provisioning rounds (Holman and Krist 2001). Pine Point does, however, have a unique profile in the local landscape. This point is the part of Douglas Lake shoreline most open to northwesterly winds (Vande Kopple, Personal Communication 2013), cold and strong winds 
that blow across the Great Lakes region (especially during winter). In the winter, Pine Point would have stayed cold longer than other parts of the lakeshore but, during dry times, Pine Point would have been more prone to forest fire (Pine Point experienced the most extensive lumber-era burnouts on Douglas lake; Vande Kopple, Personal Communication 2013). Pine Point is also the next major outcrop of Rubicon sands along Douglas Lake moving east from Grapevine Point.

Pine Point's local profile helps clarify this large isolated cluster. Local communities both protected their stores and capitalized on the microenvironment of Pine Point: a) outsiders would have not been attracted to this locale given its un-remarkableness and fire-producing winds; b) cold winter winds would have extended the storage season and c) Rubicon sands would have provided excellent drainage for the pits. Interestingly, Pine Point also falls in the viewshed of 20CN63 on Grapevine Point, while much of the rest of the shoreline of Douglas Lake does not. ${ }^{\text {iii }}$ Together, the profile of the positioning at Pine Point suggests the local inhabitants at Grapevine Point placed this set of large storage facilities where they would have been able to monitor activities around them, ensuring only those who were supposed to access them did.

The other large cluster of cache pits found to-date is, unlike Pine Point, and more expectedly for an isolated cache pit cluster, at a notable natural feature, the Little Carp River Gorge, a groundwater seep draining out of Douglas Lake colloquially called the Gorge. As the seepage has eroded the High Outwash here, it has created a visually striking series of cold water springs coming out of a major topographic cut. These springs eventually coalesce to form Carp Creek which flows into Burt Lake. Cache pits have been found ringing the high ground above the water seeps, with the most striking series of pits occurring on the east side of the Gorge (Figure 3). Here, we have found over 220 visible pits, one of the largest groups recorded in the northern Great Lakes (Figure 5). 
Shovel test survey around this large cluster of cache pits (200 x $100 \mathrm{~m}$ grid, $10 \mathrm{~m}, 200$ shovel tests) yielded only ten positive tests, but they all trended in a northwest line from the pits toward the head of the gorge (the springs), with no positive tests south or west, suggesting a possible path of use from the pits to the springs. More testing is necessary to determine the exact meaning of these finds, but the extant data indicate the Gorge did not host substantial occupation (at least in the proximate vicinity of the large group of pits).

At the Gorge, cache pits were isolated at a notable landscape feature removed from local residential activity, making this facility both physically and socially accessible to multiple groups traversing the landscape. These pits offered insurance, in the form of nutritional support, for stresses encountered during the resource provisioning rounds of many groups. In mapping the 220 pits we found this cluster has its own internal structure -- pits occur in circular (and a few linear) groupings (Figure 5). Such internal structure may reflect dispersed local groups, who inhabited sites like Grapevine Point at points during their annual mobility rounds across this lacustrine landscape, had designated sections they filled and maintained within this regionally accessible, intergroup storage facility.

\section{Building Cache Pits}

Cross-section excavations of cache pits provide insight into how groups developed techniques that ensured adequate food storage in pits, how such knowledge was embedded and transmitted, and how the time and labor costs of storage in immovable facilities were managed in pit construction, scheduling, and maintenance. At Grapevine Point two pits from the cluster of 20 on the High Terrace and one from a cluster on the High Outwash have been cross sectioned. At Pine Point, four visible pits were cross sectioned via two trenches $(11 \mathrm{~m}$. and $8 \mathrm{~m}$.) between two 
sets of pits in order to illuminate the interrelationship of pits. On the south shore of Douglas Lake (at the west side of UMBS property), cache pits from three different clusters on High Terraces were cross sectioned. At the Gorge, one cache pit was cross sectioned and one was excavated horizontally. ${ }^{\text {iv }}$ Refer to Figure 3 for the location of these clusters.

Given the detail and size of pit cross-section profile maps, only one representative pit from each landscape area has been provided (Figures 6 thru 9). To facilitate viewing, the profiles have been simplified. Each pit holds the story of the choices people made throughout the fabrication process of the cache pit, from initial construction to longer use-life in the landscape, and it is to these stories that we now turn.

Size, Capacity, Time, and Corporate Labor. Table 4 presents a summary of the surface diameter, subsurface diameter, surface depth, subsurface depth, combined maximum depth and a volume estimation for cross-sectioned pits (following closely the format of Dunham 2000:236). The mean size measurements of the sample are $207 \mathrm{~cm}$ wide (diameter at surface) and $143 \mathrm{~cm}$ deep (total estimated depth). The two shallowest pits have depths of ca. $100 \mathrm{~cm}$, and the two deepest pits have maximum depths of $185 \mathrm{~cm}$ and $174 \mathrm{~cm}$ respectively, which at close to six feet aligns with the depth Densmore (1929:40) recorded for historic cache pits. To envision the capacity reflected in these constructions, we computed an estimate of pit volume. We computed volume as a truncated cone $\left(V=\frac{1}{3} \pi\left(r_{1}^{2}+r_{1} r_{2}+r_{2}^{2}\right) h\right)$ (Table 3$)$. The average volume across excavated pits is $2.50 \mathrm{~m}^{3}$.

To provide a sense of the time involved to fill pits of these volumes, we used wellestablished estimates of acorn collection and storage among hunter-gatherers in California (see Bettinger et al. 1997 and Morgan 2012). Acorns, while not used as extensively as in California, 
were, as discussed above, still important in the Great Lakes, especially in the interior during Late Precontact, where they formed an important starch complement to the fish/meat protein in the diet here where maize was not (typically) able to be grown (Dunham 2009). Indeed, and as discussed above, in this interior lake setting, we have documented red oak (Quercus rubra) acorn storage at the Grapevine Point pits as well as the preferential placement of cache pits on oak bearing land cover types (Table 2).

We use these well-established figures from one set of foragers to create an, admittedly imperfect but still useful, rubric for thinking about the labor time it would have taken foragers in this interior lake landscape to fill pits of these volumes. We converted cubic meters to liters and then, to be conservative with our estimates, we quartered this, assuming every pit would contain at least 3/4 non-foodstuffs (packing materials, empty space) (Table 5).

Morgan (2012: 724; following Bettinger et al. 1997) estimates the amount of unhulled acorn storable per liter to be $1.45 \mathrm{~kg}$; we converted to kilograms accordingly (Table 5). Morgan (2012:726) establishes an acorn storage rate (gathering, handling, and storage) of $9 \mathrm{~kg}$ per hour; we used this rate to compute the time required to fill pits. Doing this, we find that on average, it would have taken 100.77 hours to fill a cache pit (Table 5). If one person worked 6 hour days, it would take 17 work days to fill one pit. This figure alone suggests people would have worked together in some manner to distribute this not insignificant time demand. As indicated above, all of the potential food resources local groups would have stored have restricted seasons during which they can be harvested. In the case of acorns, red oak acorns are typically only available for collection in a September/October masting window. Communities had to, then, not only find time outside of their day-to-day operations to fill cache pits they had to also ensure they did so during a set seasonal window. 
As mentioned above, one of the notable regional developments during the Late Precontact period was the rise of corporate groups. Corporate groups are, in abbreviated terms, extended kin-based units who function together economically, socially, and religiously to, respectively, materially satisfy human needs, order human relationships, and mediate relations with the supernatural (Befu and Plotnicov 1962; Fried 1957; Hickerson 1970). Corporate groups became key during Late Precontact to reduce the risks associated with having to subsist, socially and economically, in increasingly circumscribed spatial territories (O’Shea and Milner 2002). We suggest one key risk-reducing function of these extended units was the pooling and coordination of labor among dispersed groups to meet the increased and seasonally-specific temporal demands presented by cache pit food storage.

Digging Fashion. The shape of the pits reveal at least two different fashions for digging. All three pits from the clusters on the south shore/west edge of UMBS and all of the pits at Pine Point are relatively bowl shaped (Figures 7 and 8), with both sides excavated evenly, making a symmetrical u-profile. In contrast, all of the pits near Grapevine Point and the pit at the Gorge have one side that is straighter than the other (Figures 6 and 9). This modified u-shape suggests people may have had a preferred side from which they worked, creating a bowled edge on the opposing side and a straighter edge on their preferred side as they dug back towards themselves.

One explanation for these different technical construction decisions could be that they reflect constraints imposed by intended pit size, but different fashions of digging span a range of pit sizes (Table 4). Another possible constraining factor is soil, but all are located on Rubicon sands. We suggest these digging fashions reflect, instead, the fact that there were multiple ways 
one could dig adequate food storage cache pits and different approaches developed along corporate group lines.

Grapevine Point pits were associated with the Late Precontact site 20CN63, and all of the pits cross-sectioned there were a modified u-shaped style, suggesting they were dug by the families living at this site who would have been in the same corporate group and sharing in pit construction practices and learning. All of the pits at Pine Point were the same u-shaped fashion. As discussed above, this larger cache pit cluster appeared to be purposefully located so that it could be monitored by those living at Grapevine Point and so it makes sense the same digging fashion is present.

The one pit cross-sectioned at the Gorge had a modified u-shaped style like the pits at Grapevine Point. We suggested above this fixed storage facility was accessible to multiple groups. We would expect to find a variety of digging fashions present at a site used by multiple corporate groups and we may even expect digging fashions to be uniform within and vary between the internal clusters of pits we found here (Figure 5). However, only one pit was crosssectioned here before work was stopped out of respect for our project's tribal partner's concerns over the Gorge's sacredness and so this theory could not be tested further.

While increased sampling is necessary, the rise of at least two different digging fashions for cache pits in the Douglas and Burt lake landscape is interesting. These different approaches to pit shape most likely resulted from passive, habitual, bodily learning among corporate group members through the regular practice of digging pits together, reflecting isochrestic variation (Sackett 1982). As discussed above, part of the technological challenges presented by immovable food storage facilities in mobile societies is the development of adequate food storage technology and the subsequent transmission of knowledge about this technology among 
dispersed communities. Here, it appears knowledge about constructing technologically adequate immovable food storage facilities both developed and was transmitted among the region's forager-fisher-low-level horticulturalists through social means -- corporate group membership.

Access Shelves. Another interesting aspect of pit construction evident from crosssections is that a kind of access shelf on the edge of the pit may have been common. The most obvious example comes from Grapevine Point High Terrace Pit 2. On the western edge of this pit is a shallow dark basin shaped soil change (Figure 6), which, like the rest of the pit, produced no material remains. Its location and context suggest it was a small shelf dug out to aid people as they accessed the pit. Gorge Pit 1 also had a darker soil stain which could be some kind of associated shelf but more interestingly, the other side of the pit was cut such that its slope is much longer and more gradual, almost like a ramp into the pit (Figure 9). Grapevine Point High Outwash Pit 1, Pine Point Trench 1 Pit A, Pine Point Trench 2 Pit A, West Edge Cluster 1 Pit A, and West Edge Cluster 2 Pit A show similar (less striking) disturbances on upper edges of their profiles. With some kind of access feature, shelf or ramp, occurring across all locations of cache pits studied, it appears having such features was beneficial to people's use of these pits and knowledge about these technical benefits successfully circulated across communities.

Reuse. Evidence indicates that pits were reused and that fields of pits remained active as storage centers over time. Grapevine Point High Terrace Pit 2 shows stratigraphy indicating reuse (Figure 6). Inside the pit is a cut $\mathrm{A} / \mathrm{E}$ horizon which indicates this pit was originally dug, used and left open long enough for detritus to fall in and form an A horizon with an incipient $\mathrm{E}$ (a process which takes around 20 years in this area; Lemoine, personal communication, 2009; 
Figure 6). The pit experienced a major recutting at least once after a ca. 20 year interval. Pits would have had routine maintenance every time they were revisited to store or remove food but this evidence of recutting suggests pits may have been rebuilt after periods of disuse as well.

At Pine Point, buried cache pits were uncovered in both excavation trenches; two in Trench 1 and one in Trench 2 (Figure 7) (buried pit in Trench 2 produced the AMS dated ceramic). The buried pits are right near the open pits and were subject to complex infilling as people dug other pits near them (Figure 7). The horizontal excavation of a visible cache pit at the Gorge (in a 2 × 2 meter unit) also revealed buried cache pits: two definite buried pits and one possible one on the excavation unit edge (Frederick 2011). At both of these locales, people returned time and again, renewing their stores and in turn renewing these storage centers as persistent, emplaced facilities, in the landscape -- maintained, visited, revisited and remembered by local communities over generations. Cache pit construction, the removal and placement of goods within them, and their maintenance were dynamic processes that drew people into enduring relations with the landscape, its cycles of resource abundance, and the other peoples in it.

Scheduling Pit Fabrication and Resource Planning in the Annual Round. To have appropriate materials for successfully transforming cache pits from holes in the ground to functional food storage facilities, planning and preparation was necessary. Ethnohistoric and archaeological evidence indicates appropriately lining pits was key to having successful subterranean storage over the winter in the Great Lakes (Arzigian et al. 2007: 1). In experimental work on Oneota pits in Wisconsin by Arzigian et al. (2007), the importance of lining was highlighted. The one unlined pit in their experiment "produced a Fusarium mold species, which 
can produce dangerous mycotoxins" (Arzigian et al. 2007:3). This mold was not present in their lined pits, where stored food showed very little rot over the winter period except in cases where it accidentally touched the soil.

Native communities of the Great Lakes used and still use birch bark for a vast array of purposes, including canoes, house coverings, containers, and fine boxes. Birch bark was also the common lining for the cache pits found as open surface depressions today in the northern Great Lakes region (Densmore 1929:40; see also Dunham 2000). In addition, and indicated in the ethnohistoric accounts, foodstuffs placed in pits were often packaged in birch bark containers as well ("makuks" and "big puekawa sacks" referenced above). The fact that most excavated pits have been empty indicates lining was de rigueur for these features and that it, in combination with food packaging, were efficient at keeping pit contents away from the soil.

Birch bark lining and packaging, in reducing the chances of rot and spoilage of cached food, formed a key part of the answer to the technological challenges of immovable food storage facilities in this context. Access to birch bark for pit lining may have been another contributing factor to the preferential landscape placement of cache pits on Northern Hardwood forest land cover we demonstrated above as birch trees were co-dominant in these forests (Table 3). Procuring birch bark requires harvesting at exactly the right moment. If the cambium, or inner bark, of a birch tree is partially removed, the tree is scarred and that section can never again be used for harvesting; moreover, if the inner bark is completely removed, the tree is effectively girdled and will die. It is only when the birch sap is running that the outer bark can be reliably harvested without taking off the inner bark (and with skilled cuts, when the sap is running, the outer bark will literally pop off in large sheets). The sap runs in a narrow temporal window in early summer in the northern Great Lakes. Depending on how wet and warm the spring is, this 
window can vary from a few weeks to a month or so, but never much longer (Walker-Keshick, personal communication, 2010).

Making sure sufficient birch bark was harvested to fill cache pit construction needs (as well as for all the other uses of birch bark) during this narrow temporal window was another aspect of cache pit fabrication that had to be planned for and accommodated beyond day-to-day operations in the mobile societies relying on these fixed storage features. When one considers the temporal and labor demands of birch bark harvesting along with these same aspects of locally available, storable food resources it becomes clear that planning for storage in immovable facilities had to occur over the course of the entire annual round. The local wild resources that were stored in the cache pits around Douglas and Burt Lake all had to be harvested at seasonally specific times. Some storable resources had to be harvested in early spring like spring-spawns of key inland lake fish and (possibly) maple sugar and other storable resources had to be harvested in summer and early fall, like berries and acorns respectively. Additionally, beyond the foodstuffs, the technologically necessary birch bark lining had to be harvested in early summer.

The creation and preparation of the physical cache pit hole also had to be considered over the annual round while foodstuff was being harvested. Each pit, no matter in what fashion it was dug, had to be physically dug out and this took time. In an ethnohistoric account from Buffalo Bird Woman about her childhood as a Hidatsa, she explains ... "it took me two days and the good part of a third to dig a cache pit" (Wilson 1917:88). Even when a cache pit was being reused, it still required cleaning and reshaping due to the glacial, sandy soil that characterizes this lacustrine landscape (and much of the broader region). Enacting adequate pit construction technique, from digging to lining, required time and effort that had to be accommodated 
alongside plans for the seasonal collection of storable foodstuffs. Sustaining a reliable system of food storage in immovable facilities was an ongoing production.

\section{Case Study Discussion}

During Late Precontact, communities inhabiting the inland landscape around Douglas and Burt Lakes in northern Michigan practiced physical food storage in cache pits, immovable subterranean storage facilities. We found communities here recognized and responded to varied technological and landscape placement challenges emergent in the use of these fixed storage features. The spatial positioning and building of cache pits was purposeful and these features served to not just store food but also knowledge about how to sustain successful physical food storage within this specific setting.

We found communities identified specific topographic settings to build pits on that answered the ever present technological challenge of rot. They placed pits on well drained soils and on elevated landforms with physiographic settings conducive to storage. We found they placed some of their cache pit clusters on elevated landforms specifically associated with living sites which was one way of answering the landscape placement challenge of needing immovable storage facilities in locales where the people who relied on their contents would productively be able to access them. While some cache pit clusters were placed so select groups living nearby could access them, we found a major cache pit cluster was placed at a location that would have been physically and socially accessible to multiple communities. We also identified at least one cache pit cluster positioned to answer the inverse landscape placement challenge of accessibility, that of protection. One facility was positioned so as to inhibit outsider access and where groups 
responsible for this storage facility could monitor it. Different types of cache pit facilities were developed to serve the needs of variable community compositions.

Communities also preferentially placed cache pit clusters on land cover types that would have, among other things, bore more storable resources. Another landscape placement challenge of immovable storage in mobile societies is fixing facilities where people could reasonably, efficiently get locally available, storable food resources into them and this was one way of answering that challenge. Communities traversing this inland lake landscape understood the delicate rhythm of the annual round necessary for successful storage, from collecting locally available storable resources when they were in abundance to harvesting birch bark for lining to reduce pit technological failure. Such rhythms wove cache pit storage facilities into the social fabric of the mobile societies inhabiting the Douglas and Burt Lake landscape during Late Precontact.

Looking at cache pits through our cross-sections revealed more about the navigation of technological and landscape placement challenges. We found these storage features had a substantial capacity and required notable time to fill. This time had to also be aligned with the seasonal specificity of resource abundance. Corporate groups provided a means of pooled labor and time to help actualize the acquisition of storable food stuffs. Having adequate storage technology and having knowledge about this technology transmitted across dispersed communities are key challenges of the practice of food storage in fixed facilities in mobile societies. Corporate groups, it seems, were also involved in answering these challenges in Late Precontact Douglas and Burt Lake, with knowledge about how to dig out the earth so it properly became a cache pit developing and circulating through corporate group membership. We found there were at least two different ways of excavating the earth so it became a functional pit 
developed in this local landscape. Building an access shelf emerged as another aspect of technical know-how about the proper way to construct a cache pit that was developed in the area.

Our research showed people returned time and again to cache pit clusters, renewing their storage features and, in turn, renewing their connection to the places of these facilities. These cache pit clusters were emplaced facilities; they drew people into them and consequently, into relationships with the land they were dug into and with those who also dug them, used them, maintained them, and remembered them. Their emplacement on the landscape benefited not just those who first constructed them but encoded key information for those who came after, who, as they tangibly experienced these features didn't have to re-learn what topographies drained the best, what spots were best for protecting stores from outside theft, what spots were best for sharing with outsiders, what pit shapes and structures functioned best, what resources were most amenable to storage, how to make linings to keep these resources from soil and reduce rot, and the like. The construction of cache pits and the enduring material and spatial presence of these features embedded and provided opportunities to encounter hard-earned knowledge about using immovable food storage facilities to mitigate scarcity risks posed by the socioecological variability of Late Precontact. Cache pits, as they became emplaced in the landscape, helped extend the collective well-being of Late Precontact communities around Douglas and Burt Lake.

\section{Concluding Thoughts}

We have shown that around Douglas and Burt Lake, cache pit storage facilities were purposefully planned, designed, and built in ways that successfully navigated varied technological and landscape placement challenges posed by immovable food storage in mobile 
societies. The enduring presence of these immovable food storage facilities in the landscape encoded knowledge about sustaining successful food storage in this setting. Our findings are based on only a small subset of the ubiquitous cache pits of the northern Great Lakes, but the results suggest there is much to be gained by investigating cache pits in their own right as they formed emplaced features that served to enhance community well-being in the increasingly restricted socioeconomic context of Late Precontact.

At a broader level, our case shows examining immovable physical food storage, including the spatial distribution and materiality of the facilities used in this storage, in relatively low density, egalitarian, non-sedentary hunter-gatherer and low-level horticulturalist societies is a line of inquiry worth expanding in archaeology. While it has become well-recognized that such societies physically store food, and do so in a range of ways, immovable physical food storage is still typically categorized as large-scale storage. With our case, and certainly many others, there is, then, an exciting opportunity to understand how mobile societies, in fact, come to develop and sustain physical food storage in immovable facilities, disentangling further remnant associations between physical food storage and large-scale, sedentary societies.

We have shown non-sedentary hunter-gatherer and low-level horticulturalist societies face distinct technological and landscape placement challenges when they use immovable food storage facilities. Investigations of the archaeological record of fixed storage facilities offers a means of identifying the range of creative and dynamic answers developed for these challenges which will continue to broaden our views of food storage in the past. When non-sedentary hunter-gatherer and low-level horticulturalist societies practiced food storage in immovable facilities, these facilities became emplaced on the landscape, they were places that drew people into them, creating "clearings" for communities to consider, reconfigure, and/or renew patterns 
of the flow, or circulation, of socioecological knowledge through their landscapes. Examining archaeological records of immovable food storage facilities creates the opportunity to understand how these features extend such "clearings" over time. Expanding archaeological research on the enduring material and spatial presence of immovable food storage facilities will provide new insights into the social, economic, and, potentially, ideological lives, deliberations, and priorities of past mobile societies. 
Acknowledgements. We are grateful to the many people who have helped with this research, with especially deep gratitude going to Bob Vande Kopple and Kathryn Parker for their instrumental involvement. We thank the Burt Lake Band of Ottawa and Chippewa Indians for sharing their knowledge about food storage with us so generously. The University of Michigan Biological Station provided critical support and access to sites. Thank you to Katie Umans for help copy-editing. The research was supported by the National Science Foundation under \#0851096; any opinions, findings, and conclusions or recommendations expressed in this material are those of the authors and do not necessarily reflect the views of the National Science Foundation. This paper benefited tremendously from the insights of editor John O'Shea, Sean Dunham, and anonymous reviewers. Any shortcomings, of course, remain our own. 


\section{Notes}

${ }^{\mathrm{i}}$ For consistency, all radiocarbon dates calibrated to one sigma using CalPal2007_Hulu

${ }^{\text {ii }}$ Strategy inspired during visit by Dr. Janet Brashler

${ }^{\text {iii }}$ A viewshed was calculated from the lake edge of occupation at site 20CN63 in ArcGIS 9.3.1

on 30m DEM of Cheboygan County: http://www.mcgi.state.mi.us/mgdl/

${ }^{\text {iv }}$ We worked on the two pits at the Gorge before discovering the full extent $(220+$ pits). 


\section{References Cited}

Albert, D. A.

1995 Regional Landscape Ecosystems of Michigan, Minnesota, and Wisconsin: A Working Map and Classification. Gen. Tech. Rep. NC-178. St. Paul, MN: U.S. Department of Agriculture, Forest Service, North Central Forest Experiment Station. Northern Prairie Wildlife

Research Center Online. http://www.npwrc.usgs.gov/resource/1998/rlandscp/rlandscp.htm (Version 03JUN98).

Albert, D. A. and P. J. Comer

2008 Atlas of Early Michigan's Forests, Grasslands, and Wetlands. Michigan State University Press, East Lansing, MI.

Albert, D. A. and L. Minc

1987 The Natural Ecology and Cultural History of the Colonial Point Red Oak Stands. A Report to the University of Michigan Biological Station (on file at UMBS).

Ames, K. M.

1994 Northwest Coast: Complex Hunter-Gatherers, Ecology, and Social Evolution. Annual Review of Anthropology 23:209-229.

2003 The Northwest Coast. Evolutionary Anthropology 1:19-33. 
Aporta, C.

2009 The Trail as Home: Inuit and their Pan-Arctic Network of Routes. Human Ecology 37: $131-146$.

Arnold, J. E. (editor)

1996 Emergent Complexity: The Evolution of Intermediate Societies. International Monographs in Prehistory, Ann Arbor, MI.

Arzigian, C. M., W. Holtz-Leith, and D. Martinek

2007 Pit Storage and Plant Foods: Ethnographic, Experimental, and Archaeological Evidence. Manuscript on file at Mississippi Valley Archaeology Center, University of Wisconsin-La Crosse (cited with lead author permission).

Basso, Keith H.

1996 Wisdom Sits in Places: Landscape and Language Among the Western Apache. University of New Mexico Press, Albuquerque.

Befu, H. and L. Plotnicov

1962 Types of Corporate Unilineal Descent Groups. American Anthropologist 64:313-327.

Bettarel, R. L. and H. G. Smith

1973 The Moccasin Bluff Site and the Woodland Cultures of Southwestern Michigan.

Anthropological Papers, no. 49, University of Michigan, Museum of Anthropology, Ann Arbor. 
Bettinger, Robert L., Malhi, Ripan, and Helen McCarthy

1997 Central Place Models of Acorn and Mussel Processing. Journal of Archaeological Science 24:887-899.

Binford, Lewis R.

1980 Willow Smoke and Dogs' Tails: Hunter-Gatherer Settlement Systems and Archaeological Site Formation. American Antiquity 45:4-20.

Blackbird, Andrew J.

1887 History of the Ottawa and Chippewa Indians of Michigan. The Ypsilantian Job Printing House, Ypsilanti, MI.

Brenton, Barrett P.

1988 The Seasonality of Storage. In Coping with Seasonal Constraints, edited by R. HussAshmore, pp. 45-54. University of Pennsylvania Museum of Archaeology, Philadelphia, PA.

Brown, Charles E.

1917 Antiquities of Green Lake. Wisconsin Archeologist 16(1): 1-55.

Cashdan, E.

1985 Coping with Risk: Reciprocity among the Basarwa of Northern Botswana. Man (New Series) 20:454-474. 
Chu, J.

2006 To be "Emplaced": Fuzhounese Migration and the Politics of Destination. Identities:

Global Studies in Culture and Power 13:395-425.

Cleland, C. E.

1982 The Inland Shore Fishery of the Northern Great Lakes: Its Development and Importance in Prehistory. American Antiquity 47:761-784.

1992 Rites of Conquest: The History and Culture of Michigan's Native Americans. University of Michigan Press, Ann Arbor.

Crawford, G. W., and Smith, D. G., and V. E. Bowyer

1997 Dating the Entry of Corn (Zea mays) into the Lower Great Lakes Region. American Antiquity 62(1):112-119.

Cunningham, $\mathrm{P}$.

2011 Caching Your Savings: The Use of Small-scale Storage in European Prehistory. Journal of Anthropological Archaeology 30:135-144.

Darling, J.A.

2009 O’odham Trails and the Archaeology of Space. In Landscapes of Movement: Trails, Paths, and Roads in Anthropological Perspective edited by J. Snead, C. Erickson, and J.A. 
Darling, pp. 61-83. University of Pennsylvania Museum of Archaeology and Anthropology, Philadelphia, PA.

DeBoer, W. R.

1988 Subterranean Storage and the Organization of Surplus: The View from Eastern North America. Southeastern Archaeology 7:1-20.

Densmore, F.

1929 Chippewa Customs. Smithsonian Institution Bureau of American Ethnology Bulletin 86. U.S. Govt., Washington, DC.

Dunham, S. B.

2000 Cache Pits: Ethnohistory, Archaeology, and the Continuity of Tradition. In Interpretations of Native North American Life: Material Contributions to Ethnohistory, edited by M. Nassaney and E. S. Johnson, pp. 225-260. University of Florida Press, Gainesville.

2009 Nuts about Acorns: A Pilot Study on Acorn Use in Woodland Period Subsistence in the Eastern Upper Peninsula of Michigan. Wisconsin Archeologist 90:113-130.

Dustin, F.

1966 Prehistoric Storage Pits in Saginaw County, Michigan. Michigan Archaeologist 14:48-52. 
Erickson, C.

2009 Agency, Causeways, Canals, and the Landscapes of Everyday Life in the Bolivian Amazon. In Landscapes of Movement: Trails, Paths, and Roads in Anthropological Perspective, edited by J. E. Sneed, C. E. Erickson, and J. A. Darling, pp. 204-231. University of Pennsylvania Press, Philadelphia, PA.

Fitzhugh, B.

2002 Residential and Logistical Strategies in the Evolution of Complex Hunter-Gatherers on the Kodiak Archipelago. In Beyond Foraging and Collecting: Evolutionary Change in Hunter Gatherer Settlement Systems, edited by B. Fitzhugh and J. Habu, pp. 257-306. Springer Publishing, New York.

Francis, D. R.

2001 A Record of Hypolimnetic Oxygen Conditions in a Temperate Multi-Depression Lake from Chemical Evidence and Chironomid Remains. Journal of Paleolimnology 25:351-365.

Frederick, K. M.

2011 When the Wild Strawberries are in Bloom: Food Caching in Northern Michigan. Unpublished Master's Thesis, Wayne State University, Detroit, MI.

Fried, M. H.

1957 The Classification of Corporate Unilineal Descent Groups. Journal of the Royal Anthropological Institute 87:1-29. 
Frink, L.

2007 Storage and Status in Precolonial and Colonial Coastal Western Alaska. Current Anthropology 48:349-374.

Funk, C.

2011 Yup'ik Eskimo Gendered Information Storage Patterns. In Information and Its Role in Hunter-Gatherer Bands, edited by R. Whallon, W. A. Lovis and R. K. Hitchcock, pp. 29-58. Cotsen Institute of Archaeology Press, Ideas, Debates, and Perspectives 5, University of California Los Angeles, Los Angeles.

Goland, C.

1991 Ecological Context of Hunter-Gatherer Storage: Environmental Predictability and Environmental Risk. In Foragers in Context: Long-term, Regional, and Historical Perspectives in Hunter Gatherer Studies, pp. 107-120. vol. 10. Michigan Discussions in Anthropology, Ann Arbor.

Gray, J.

2011 Building a House in Nepal: Auspiciousness as a Practice of Emplacement. Social Analysis 55:73-93. 
Greenman, E.

1926 Michigan Mounds, with Special Reference to Two in Missaukee County. In Papers of the Michigan Academy of Science, Arts, and Letters, Vol. 7, pp.1-9. Museum of Anthropology, University of Michigan, Ann Arbor.

Grier, C., J. Kim and J. Uchiyama (editors)

2006 Beyond Affluent Foragers: Rethinking Hunter-Gatherer Complexity. Oxbow Books, Oxford.

Halperin, R. H.

1994 Cultural Economies Past and Present. University of Texas Press, Austin.

Halstead, P. and J. O'Shea

1989 Introduction: Cultural Responses to Risk and Uncertainty. In Bad Year Economics:

Cultural Responses to Risk and Uncertainty, edited by P. Halstead and J. O'Shea, pp. 1-8. Cambridge University Press, Cambridge.

Hambacher, M. J.

1992 The Skegemog Point Site; Continuing Studies in the Cultural Dynamics of the Carolinian-Canadian Transition Zone. Unpublished PhD Dissertation, Michigan State University, East Lansing. 
Hambacher, M. J. and M. B. Holman (with contributions from K. C. Egan and B. A. Smith) 1995 Camp, Cache and Carry: The Porter Creek South Site (20MN100) and Cache Pits at 20MN31 in the Manistee National Forest. Michigan Archaeologist 41:47-94.

Hart, J. P. and W. A. Lovis

2013 Reevaluating What We Know About the Histories of Maize in Northeastern North America: A Review of Current Evidence. Journal of Archaeological Research 21(2):175-216.

Hendon, J. A.

2000 Having and Holding: Storage, Memory, Knowledge, and Social Relations. American Anthropologist 102:42-53.

Hickerson, $\mathrm{H}$.

1970 The Chippewa and Their Neighbors: A Study in Ethnohistory. Holt, Rinehart and Winston, New York, NY.

Hinsdale, W.B.

1931 Archaeological Atlas of Michigan. University of Michigan Press, Ann Arbor, MI.

Holman, M. B.

1978 The Settlement System of the Mackinac Phase. Unpublished PhD Dissertation, Michigan State University. 
1984 The Identification of Late Woodland Maple Sugaring Sites in the Upper Great Lakes. Midcontinental Journal of Archaeology 9:63-89.

Holman, M. B. and F.J. Krist

2001 Late Woodland Storage and Mobility in Western Lower Michigan. Wisconsin Archeologist: Papers in Honor of Carol I Mason 2:7-32.

Holman, M.t B. and W. A. Lovis

2008 The Social and Environmental Constraints on Mobility in the Late Prehistoric Upper Great Lakes Region. In The Archaeology of Mobility: Old and New World Nomadism, edited by H. Barnard and W. Wendrich, pp. 280-306. Cotsen Advanced Seminars 4. Cotsen Institute of Archaeology, University of California, Los Angeles.

Howey, M. C.L.

2012 Mound Builders and Monument Makers of the Northern Great Lakes, 1200-1600. University of Oklahoma Press, Norman, OK.

2015 Geospatial Landscape Permeability Modeling for Archaeology: A Case Study of Food Storage in Northern Michigan. Journal of Archaeological Science 64:88-99.

Howey, M. C.L. and K. Parker

2008 Camp, Cache, Stay Awhile: Preliminary Considerations of the Social and Economic Processes of Cache Pits along Douglas Lake, MI. Michigan Archaeologist 54: 19-43 
Ingold, T.

1983 The Significance of Storage in Hunting Societies. Man 18:553-71.

Jochim, M.

1981 Strategies for Survival. Academic Press, New York.

Katzenberg, M. A., H. Schwarcz, M. Knyf, and F.J. Melbye

1995 Stable Isotope Evidence for Maize Horticulture and Paleodiet in Southern Ontario, Canada. American Antiquity 60(2):335-350.

Keeley, L. H.

1988 Hunter-Gatherer Economic Complexity and 'Population Pressure': A Cross-Cultural Analysis. Journal of Anthropological Archaeology 7:373-411.

Kinietz, W. V.

1947 Chippewa Village: The Story of Katikitegon. Cranbrook Institute of Science, Bloomfield Hills, MI.

Koyama, S. and D. H. Thomas (editors)

1981 Affluent Foragers: Pacific Coasts East and West. Senri Ethnological Studies 9. National Museum of Ethnology, Osaka. 
Kuijt, I.

2009 What Do We Really Know About Food Storage, Surplus, and Feasting in Preagricultural Communities? Current Anthropology 50:641-644.

Lemoine, J.

2009 Personal Communication, University of Michigan Biological Station (Lead Field Soil

Scientist, University of Michigan Biological Station and Department of Ecology and

Evolutionary Biology).

Lovis, W. A.

1976 Quarter Sections and Forests: An Example of Probability Sampling in the Northeastern Woodlands. American Antiquity 41:364-372.

Lovis, W. A. and R. E. Donahue

2011 Space, Information and Knowledge: Ethnocartography and North American Boreal Forest Hunter-Gatherers. In Information and Its Role in Hunter-Gatherer Bands edited by R. Whallon, W. A. Lovis and R. K. Hitchcock, pp. 59-88. Cotsen Institute of Archaeology Press, Ideas, Debates, and Perspectives 5, University of California Los Angeles, Los Angeles..

Low, S. M. and D. Lawrence-Zúñiga

2003 Locating Culture. In The Anthropology of Space and Place: Locating Culture, edited by S. M. Low and D. Lawrence-Zúñiga, pp. 1-48. Blackwell, Malden. 
Martin, S. W. J.

2008 Languages Past and Present: Archaeological Approaches to the Appearance of Northern Iroquoian Speakers in the Lower Great Lakes Region of North America. American Antiquity 73(3):441-463.

Milner, C. McHale

1998 Ceramic Style, Social Differentiation, and Resource Uncertainty in the Late Prehistoric Upper Great Lakes. Unpublished PhD Dissertation, University of Michigan.

Minc, L.

1986 Scarcity and Survival: The Role of Oral Tradition in Mediating Subsistence Crisis. Journal of Anthropological Archaeology 5: 39-113.

Minc, L. and K. Smith

1989 The Spirit of Survival: Cultural Responses to Resource Variability in North Alaska. In Bad Year Economics: Cultural Responses to Risk and Uncertainty, edited by P. Halstead and J. O'Shea, pp. 8-39. Cambridge University Press, Cambridge.

Morgan, C.

2012 Modeling Modes of Hunter-Gatherer Food Storage. American Antiquity 77:714-736. 
Munn, N. D.

1977 The Spatiotemporal Transformation of Gawa Canoes. Journal de la Societe des Oceanistes 33:39-53.

Myers, F.

2013 Emplacement and Displacement: Perceiving the Landscape through Aboriginal Australian Acrylic Painting. Ethnos: Journal of Anthropology 78:435-463.

Norder, J. W.

2003 Marking Place and Creating Space in Northern Algonquian Landscapes: The Rock-art of the Lake of the Woods Region, Ontario. Unpublished Ph.D. dissertation, University of Michigan, Ann Arbor, MI.

O'Gorman, J.A.

2007 The Myth of Moccasin Bluff: Rethinking the Potawatomi Pattern Ethnohistory 54:373406.

O’Gorman, J.A. and W.A. Lovis

2006 Before Removal: An Archaeological Perspective on the Southern Lake Michigan Basin. Midcontinental Journal of Archaeology (special issue: The Potawatomi Removal, edited by M. Schurr) 31: $21-56$. 
O'Shea, J. M.

1981 Coping with Scarcity: Exchange and Social Storage. In Economic Archaeology, edited by A. Sheridan and G.N. Bailer, pp. 167-183. British Archaeological Reports (International Series 96), Oxford.

1989a The Role of Wild Resources in Small-Scale Agricultural Systems: Tales from the Lakes and the Plains. In Bad Year Economics: Cultural Responses to Risk and Uncertainty, edited by P. Halstead and J. O'Shea, pp. 57-67. Cambridge University Press, Cambridge.

1989b Black River Cache, 20AA54. Draft manuscript on file University of Michigan Museum of Anthropology, Ann Arbor.

2003 Inland Foragers and the Adoption of Maize Agriculture in the Upper Great Lakes of North America. Before Farming: The Archaeology of Old-World Hunter-Gatherers 2(3):1-21.

O’Shea, J. M. and C. McHale Milner

2002 Material Indicators of Territory, Identity, and Interaction in a Prehistoric Tribal System. In The Archaeology of Tribal Societies, edited by W. A. Parkinson, pp. 200-226. International Monographs in Prehistory, Ann Arbor.

Parker, K.

2009 Personal Communication, University of Michigan Biological Station (Paleoethnobotanist, Great Lakes Ecosystems). 
Pearsall, D.s R., B.V. Barnes, G. R. Zogg, M. Lapin and R. R. Ring (editors)

1995 Landscape Ecosystems of the University of Michigan Biological Station. School of Natural Resources \& Environment. University of Michigan, Ann Arbor.

Petruso, K. and J. Wickens

1984 The Acorn in Aboriginal Subsistence in Eastern North America: A Report on Miscellaneous Experiments. In Experiments and Observations on Aboriginal Wild Plant Food Utilization in Eastern North America, edited by P. Munson, pp. 360-378. Indiana Historical Society, Indianapolis.

Raviele, M.

2010 Assessing Carbonized Archaeological Cooking Residues: Evaluation of Maize Phytolith Taphonomy and Density through Experimental Residue Analysis. PhD Dissertation, Michigan State University.

Rowley-Conwy, P.and M.Zvelebil

1989 Saving it for Later: Storage by Prehistoric Hunter-Gatherers in Europe. In Bad Year Economics: Cultural Responses to Risk and Uncertainty, edited by P. Halstead and J. M. O’Shea, pp. 40-56. Cambridge University Press, Cambridge.

Sackett, J. R.

1982 Approaches to Style in Lithic Archaeology. Journal of Anthropological Archaeology 1:59-112. 
Sahlins, M.

1972 Stone Age Economics. Aldine, Chicago.

Sakaguchi, T.

2009 Storage Adaptation among Hunter-Gatherers: A Quantitative Approach to the Jomon

Period. Journal of Anthropological Archaeology 28:290-303.

Schneider, R.

1942 Report of Cleaning Out a Cache Pit. Totem Pole 10:5.

Schumacher, J. P.

1918 Indian Remains in Door County. Wisconsin Archeologist 16(4).

Simms, S. R.

2008 Ancient Peoples of the Great Basin and Colorado Plateau. Left Coast Press, Walnut Creek, CA.

Soil Survey Staff, Natural Resources Conservation Service, United States Department of Agriculture

2010 Soil Series Classification Database [Online WWW]. Available URL:

http://soils.usda.gov/soils/technical/classification/scfile/index.html [Accessed 15 August, 2010]. USDA-NRCS, Lincoln, NE. 
Soffer, O.

1989 Storage, Sedentism, and the Eurasian Paleolithic Record. Antiquity 63:719-732.

Spielmann, K. A.

1983 Late Prehistoric Exchange Between the Southwest and Southern Plains. Plains Anthropologist 28(1):257-72.

Stewart, P. and A. Strathern

2005 Body and Mind on the Move: Emplacement, Displacement, and Trans-placement in Highlands Papua New Guinea.

http://www.rchss.sinica.edu.tw/capas/publication/newsletter/N27/2704_03.pdf

Stopp, M. P.

2002 Ethnohistoric Analogues for Storage as an Adaptive Strategy in Northeastern Subarctic Prehistory. Journal of Anthropological Archaeology 21:301-328.

Tanner, J.

1940[1830] An Indian Captivity (1789-1822) (edited by E. James). Occasional Papers, Reprint Series No. 20. California State Library, San Francisco.

Testart, A.

1982 The Significance of Food Storage among Hunter-Gatherers: Residence Patterns, Population Densities, and Social Inequalities. Current Anthropology 23:523-537. 
Trigger, B.

1990 Monumental Architecture: A Thermodynamic Explanation of Symbolic Behaviour. World Archaeology 22(2):119-132.

Tushingham, S. and R. L. Bettinger

2013 Why Foragers Choose Acorns before Salmon: Storage, Mobility, and Risk in Aboriginal California. Journal of Anthropological Archaeology 32:527-537.

Vande Kopple, R.

2013 Personal Communication. Fall 2013, email exchanges. (University of Michigan

Biological Station Resident Biologist).

Walker Keshick, Y.

2010 Personal Communication, June 2010 University of Michigan Biological Station (Renowned Porcupine Quillworker, Little Traverse Bay Band of Odawa Indians).

Whallon, R.

2011 An Introduction to Information and its Role in Hunter-Gatherer Bands. In Information and Its Role in Hunter-Gatherer Bands edited by R. Whallon, W. A. Lovis and R. K. Hitchcock, pp. 1-28. Cotsen Institute of Archaeology Press, Ideas, Debates, and Perspectives 5, University of California Los Angeles, Los Angeles. 
Whelan, C. S., A. R. Whitaker, J. S. Rosenthal and E. Woohlgemuth

2013 Hunter-Gatherer Storage, Settlement, and the Opportunity Costs of Woman's Foraging. American Antiquity 78: 662-678.

Wiessner, P.

1982 Risk, Reciprocity and Social influences on !Kung San Economics. In Politics and History in Band Societies, edited by E. Leacock and R. B. Lee, pp. 61-84. Cambridge University Press, Cambridge.

Wilson, G.L.

1917 Agriculture of the Hidatsa Indians: An Indian Interpretation. Cornell University Library (2009), Cornell, NY.

Zedeno, M., Hollenback, K. and C. Grinnell

2009 From Path to Myth: Journeys and the Naturalization of Territorial Identity along the Missouri River. In Landscapes of Movement: Trails, Paths, and Roads in Anthropological Perspective edited by J. Snead, C. Erickson, and J.A. Darling, pp. 106-132. University of Pennsylvania Museum of Archaeology and Anthropology, Philadelphia, PA. 
Tables

\begin{tabular}{|l|l|l|l|}
\hline \multicolumn{1}{|c|}{ SSURGO Soil Series } & \multicolumn{1}{|c|}{$\begin{array}{c}\text { Soil Drainage } \\
\text { Characterization }\end{array}$} & $\begin{array}{l}\text { Percent of Study Area in } \\
\text { Soil }\end{array}$ & \multicolumn{1}{c|}{$\begin{array}{c}\text { Percent of Cache Pit } \\
\text { Clusters on Soil }\end{array}$} \\
\hline Rubicon & Excessively Drained & $\begin{array}{l}29.3 \% \\
(19353260 \text { sq. } \mathrm{m})\end{array}$ & $88.00 \%(59)$ \\
\hline Rousseau & Well Drained & $\begin{array}{l}0.9 \% \\
(599698 \text { sq. m) }\end{array}$ & $4.5 \%(3)$ \\
\hline Blue Lake & Well Drained & $\begin{array}{l}5.3 \% \\
(3504242 \text { sq. m) }\end{array}$ & $3 \%(2)$ \\
\hline Croswell & Moderately Well & $\begin{array}{l}1.3 \% \\
(863839 \text { sq. m) }\end{array}$ & $3 \%(2)$ \\
\hline Cheboygan & Drained & $\begin{array}{l}11.8 \% \\
(7795322.87 \text { sq. m) }\end{array}$ & $1.5 \%(1)$ \\
\hline Other Soil Series & Moderately Well & $\begin{array}{l}51.4 \% \\
(33949751 \text { sq. m) }\end{array}$ & $0 \%(0)$ \\
\hline
\end{tabular}

Table 1. Distribution of Cache Pit Clusters on Soil Series in the Study Area (2-km out from

Douglas and Burt Lake on UMBS property; SSURGO soils data acquired from

http://www.mcgi.state.mi.us/mgdl/; soil polygon clipped to cache pit survey area polygon;

summary statistics computed on soil series area attribute table; cache pit point file spatially

joined to soil series working in ArcGIS 10.2) 


\begin{tabular}{|l|l|l|}
\hline Pre-European Landcover Group & $\begin{array}{c}\text { Percent of Study Area in Land } \\
\text { Cover Group }\end{array}$ & $\begin{array}{c}\text { Percent of Cache Pit Clusters on } \\
\text { Land Cover Group }\end{array}$ \\
\hline $\begin{array}{l}\text { Laurentian-Acadian Northern } \\
\text { Hardwoods }\end{array}$ & $\begin{array}{l}51.8 \% \\
(34214400 \text { sq. m) }\end{array}$ & $74.63 \%(50)$ \\
\hline Conifer & $\begin{array}{l}10.4 \% \\
(6885900 \text { sq. m) }\end{array}$ & $10.45 \%(7)$ \\
\hline Mixed Laurentian-Acadian & $\begin{array}{l}\text { (6.25\% } \\
\text { Northern Hardwood-Conifer }\end{array}$ & $14.92 \%(10)$ \\
\hline Misc. Other Landcover types & $31.55 \%$ & sq. m) \\
$(20819700$ sq. m) & $0 \%(0)$ \\
\hline
\end{tabular}

Table 2. Distribution of Cache Pit Clusters on Major pre-Euro-American Settlement Land Cover

Categories in the Study Area (2-km out from Douglas and Burt Lake on UMBS property;

Biophysical Setting landcover raster from LANDFIRE http://www.landfire.gov/; cache pit survey area converted to raster and added to landcover raster with raster calculator; values extracted from this raster to cache pit point file working in ArcGIS 10.2) 


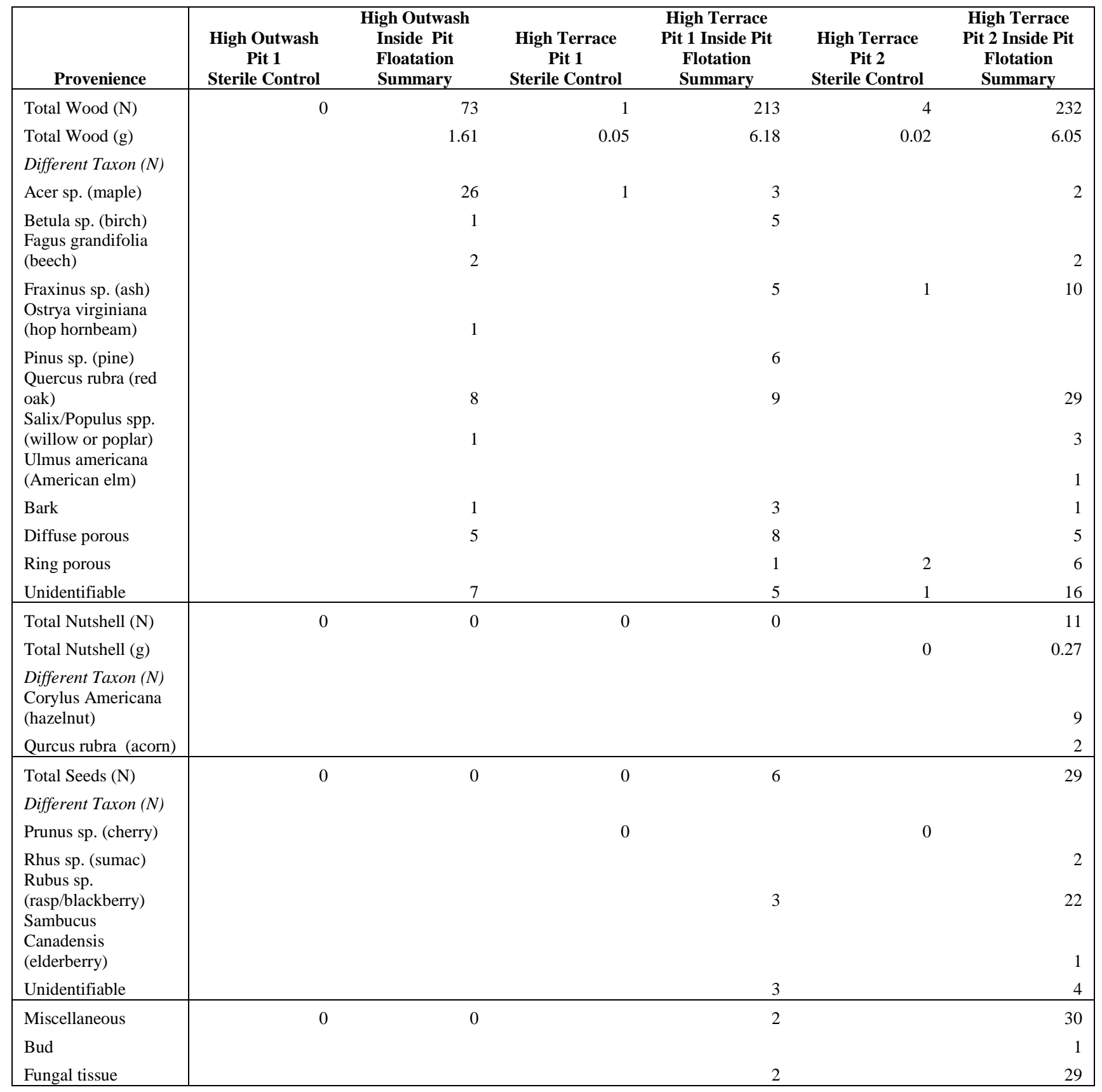

Table 3. Floral remains from Flotations taken during Grapevine Point Cache Pit Cross-Sections 


\begin{tabular}{|c|c|c|c|c|c|c|}
\hline $\begin{array}{c}\text { Excavated Cache } \\
\text { Pit }\end{array}$ & $\begin{array}{l}\text { Diameter at } \\
\text { Surface } \\
\text { (cm) }\end{array}$ & $\begin{array}{c}\text { Diameter } \\
\text { estimated at } \\
\text { subsurface } \\
\text { base } \\
\text { (cm) }\end{array}$ & $\begin{array}{l}\text { Maximum } \\
\text { Depth of Pit } \\
\text { on Surface } \\
\text { (cm) }\end{array}$ & $\begin{array}{l}\text { Maximum } \\
\text { depth of pit } \\
\text { Subsurface } \\
\quad(\mathrm{cm})\end{array}$ & $\begin{array}{c}\text { Total } \\
\text { Estimated } \\
\text { Depth of Pit } \\
\text { (surface }+ \\
\text { subsurface } \\
\text { depth) }(\mathrm{cm})\end{array}$ & $\begin{array}{c}\text { Estimated } \\
\text { Volume } \\
\text { (cubic m) }\end{array}$ \\
\hline $\begin{array}{l}\text { Grapevine Point } \\
\text { High Terrace Pit } 1\end{array}$ & 148 & 69 & 17 & 82 & 99 & 0.96 \\
\hline $\begin{array}{l}\text { Grapevine Point } \\
\text { High Terrace Pit } 2\end{array}$ & 220 & 96 & 70 & 115 & 185 & 3.81 \\
\hline $\begin{array}{l}\text { Grapevine Point } \\
\text { High Outwash Pit } \\
1\end{array}$ & 200 & 94 & 55 & 85 & 140 & 2.48 \\
\hline $\begin{array}{l}\text { Pine Point Trench } \\
2 \text { Pit A }\end{array}$ & 135 & 73 & 21 & 85 & 106 & 0.93 \\
\hline $\begin{array}{l}\text { Pine Point Trench } \\
2 \text { Pit B }\end{array}$ & 162 & 61 & 29 & 112 & 141 & 1.47 \\
\hline $\begin{array}{l}\text { Pine Point Trench } \\
1 \text { Pit A }\end{array}$ & 280 & 70 & 42 & 115 & 157 & 4.23 \\
\hline $\begin{array}{l}\text { Pine Point Trench } \\
1 \text { Pit B }\end{array}$ & 270 & 65 & 62 & 112 & 174 & 4.31 \\
\hline $\begin{array}{l}\text { The Gorge } \\
\text { Pit } 1\end{array}$ & 230 & 63 & 18 & 118 & 136 & 2.54 \\
\hline $\begin{array}{l}\text { West Edge Cluster } \\
1 \text { Pit A }\end{array}$ & 200 & 48 & 27 & 116 & 143 & 1.94 \\
\hline $\begin{array}{l}\text { West Edge Cluster } \\
2 \text { Pit A }\end{array}$ & 225 & 55 & 51 & 112 & 163 & 2.82 \\
\hline $\begin{array}{l}\text { West Edge Cluster } \\
3 \text { Pit A }\end{array}$ & 210 & 65 & 40 & 85 & 125 & 2.03 \\
\hline $\begin{array}{c}\text { Mean } \\
\text { Measurements }\end{array}$ & 207.27 & 69 & 39.27 & 103.36 & 142.64 & 2.50 \\
\hline
\end{tabular}

Table 4. Size Measurements and Volume Estimation (as a truncated cone) for Cross-Sectioned

Cache Pits on UMBS Property 


\begin{tabular}{|c|c|c|c|c|c|}
\hline $\begin{array}{c}\text { Excavated Cache } \\
\text { Pit }\end{array}$ & $\begin{array}{c}\text { Estimated } \\
\text { Volume } \\
\text { (cubic } \\
\text { meters) }\end{array}$ & $\begin{array}{c}\text { Estimated } \\
\text { Capacity for } \\
\text { Foodstuffs in } \\
\text { Liters (1/4 } \\
\text { total liters) }\end{array}$ & $\begin{array}{c}\text { Estimated } \\
\text { Kilogram } \\
\text { Capacity for } \\
\text { Unhulled } \\
\text { Acorns }\end{array}$ & $\begin{array}{l}\text { Estimated } \\
\text { time to meet } \\
\text { kilogram } \\
\text { capacity in } \\
\text { hours }\end{array}$ & $\begin{array}{c}\text { Estimated } \\
\text { work days } \\
\text { involved to } \\
\text { meet } \\
\text { kilogram } \\
\text { capacity }\end{array}$ \\
\hline $\begin{array}{l}\text { Grapevine Point } \\
\text { High Terrace Pit } 1\end{array}$ & 0.96 & 240 & 348 & 38.66 & 6.5 \\
\hline $\begin{array}{l}\text { Grapevine Point } \\
\text { High Terrace Pit } 2\end{array}$ & 3.81 & 952.5 & 1381.125 & 153.46 & 25.5 \\
\hline $\begin{array}{l}\text { Grapevine Point } \\
\text { High Outwash Pit } \\
1\end{array}$ & 2.48 & 620 & 899 & 99.89 & 16.5 \\
\hline $\begin{array}{l}\text { Pine Point Trench } \\
2 \text { Pit A }\end{array}$ & 0.93 & 232.5 & 337.125 & 37.46 & 6 \\
\hline $\begin{array}{l}\text { Pine Point Trench } \\
2 \text { Pit B }\end{array}$ & 1.47 & 367.5 & 532.875 & 59.21 & 10 \\
\hline $\begin{array}{l}\text { Pine Point Trench } \\
1 \text { Pit A }\end{array}$ & 4.23 & 1057.5 & 1533.375 & 170.375 & 28 \\
\hline $\begin{array}{l}\text { Pine Point Trench } \\
1 \text { Pit B }\end{array}$ & 4.31 & 1077.5 & 1562.375 & 173.60 & 29 \\
\hline $\begin{array}{l}\text { The Gorge } \\
\text { Pit } 1\end{array}$ & 2.54 & 635 & 920.75 & 102.31 & 17 \\
\hline $\begin{array}{l}\text { West Edge Cluster } \\
1 \text { Pit A }\end{array}$ & 1.94 & 485 & 703.25 & 78.14 & 13 \\
\hline $\begin{array}{l}\text { West Edge Cluster } \\
2 \text { Pit A }\end{array}$ & 2.82 & 705 & 1022.25 & 113.58 & 19 \\
\hline $\begin{array}{l}\text { West Edge Cluster } \\
3 \text { Pit A }\end{array}$ & 2.03 & 507.5 & 735.875 & 81.76 & 13.5 \\
\hline $\begin{array}{c}\text { Mean } \\
\text { Figures }\end{array}$ & 2.50 & 625.45 & 906.9 & 100.77 & 17 \\
\hline $\begin{array}{l}\text { Notes on } \\
\text { Calculations used } \\
\text { in Column }\end{array}$ & $\begin{array}{l}\text { Truncated } \\
\text { cone }\end{array}$ & $\begin{array}{l}1 \text { cubic meter } \\
=1000 \text { liters }\end{array}$ & $\begin{array}{l}1.45 \mathrm{~kg} \text { per } \\
\text { liter unhulled } \\
\text { acorns }\end{array}$ & $\begin{array}{c}9 \mathrm{~kg} / \text { hour to } \\
\text { store unhulled } \\
\text { acorns }\end{array}$ & $\begin{array}{c}6 \text { hour work } \\
\text { days, nearest } \\
\text { half day }\end{array}$ \\
\hline
\end{tabular}

Table 5. Time Estimates to Fill Cross-Sectioned Cache Pits on UMBS Property (Figures for

calculations based on the work of Bettinger et al. 1997 and Morgan 2012 on acorn collecting and storage among California hunter-gatherers. We are aware the specific circumstances of food collection differ in our case study; we used these figures from well-established studies as a means of thinking about the time that may have been involved in cache pit filling in our area. We do not intend them as definitive or exact estimates.) 


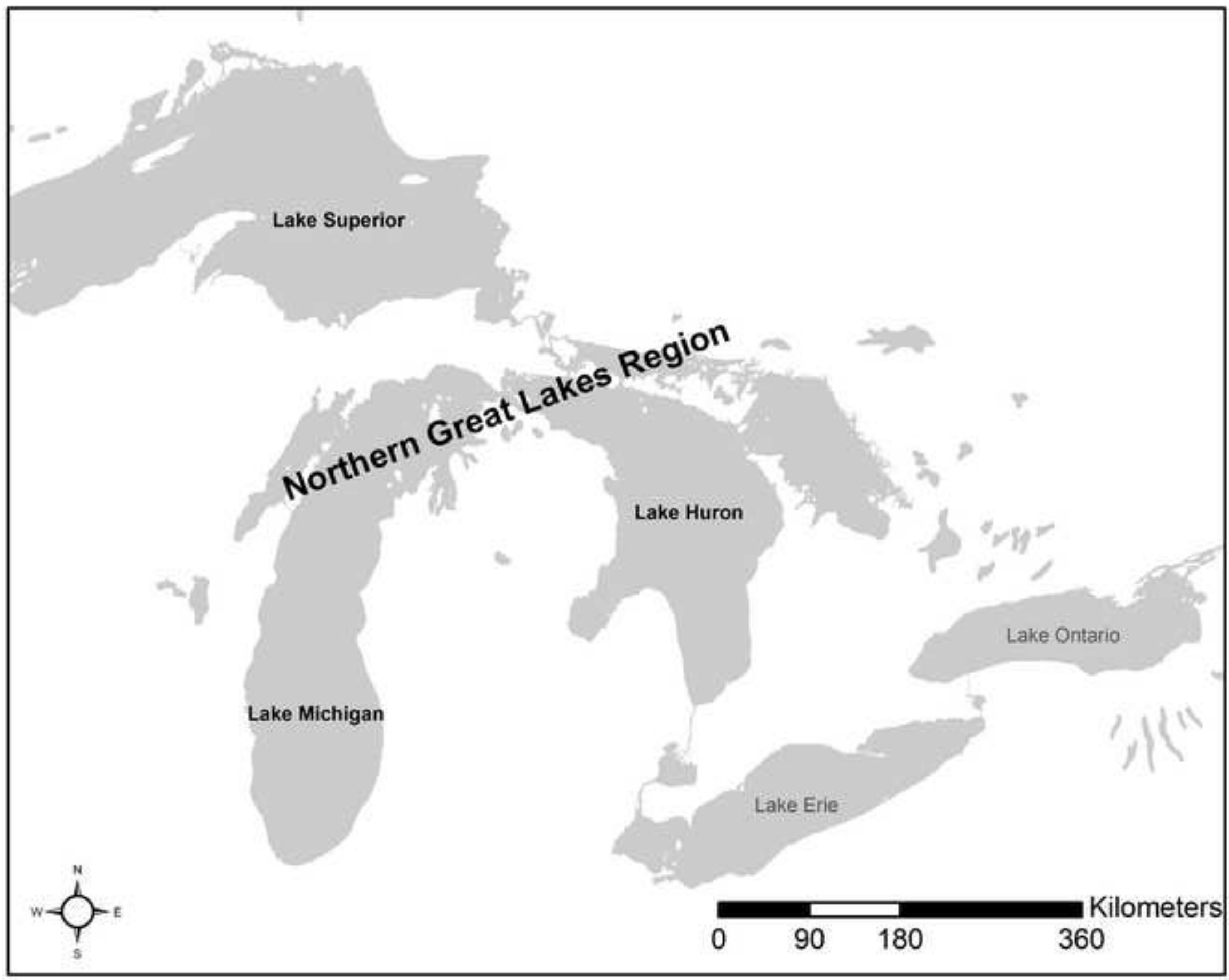




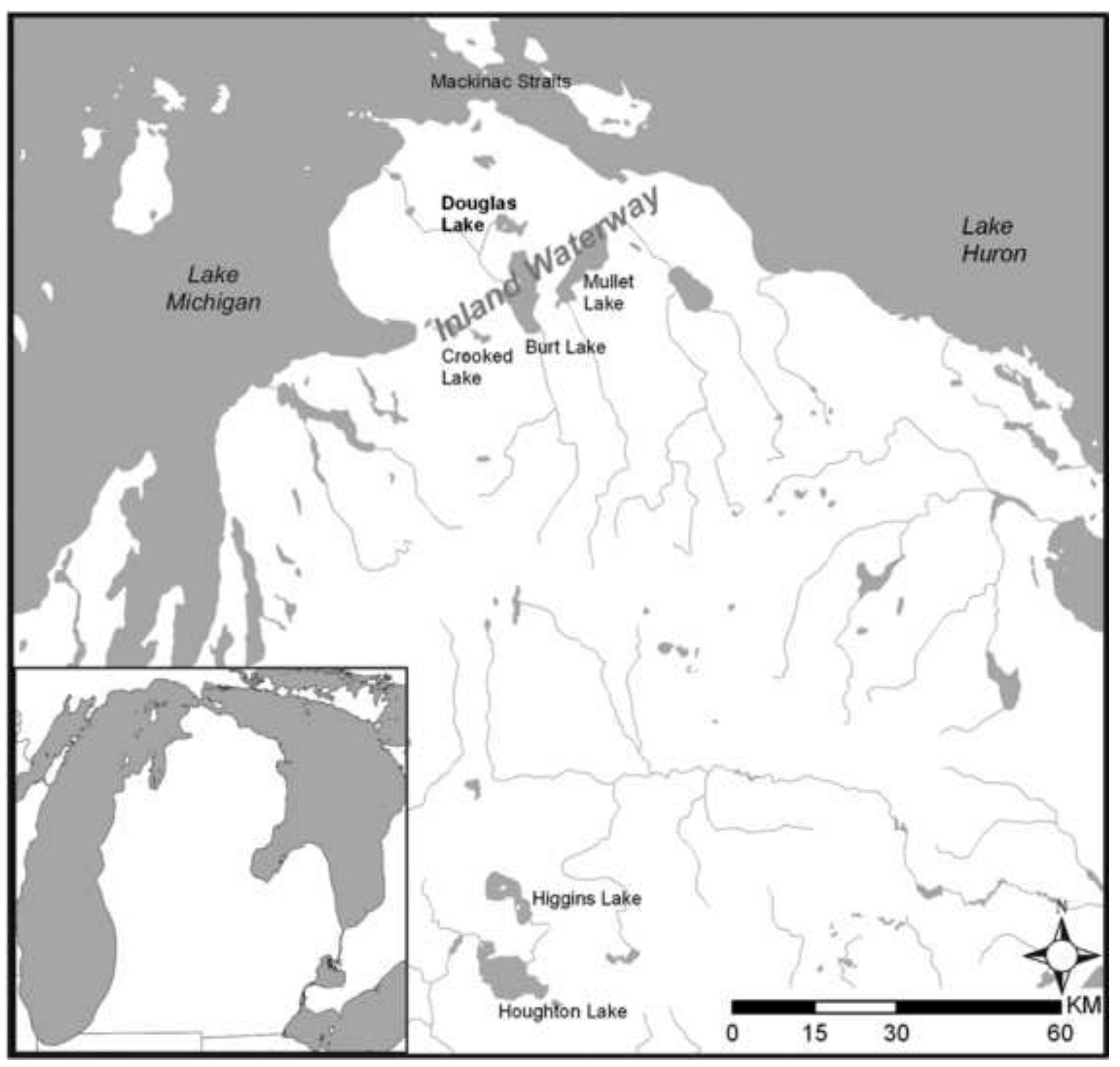




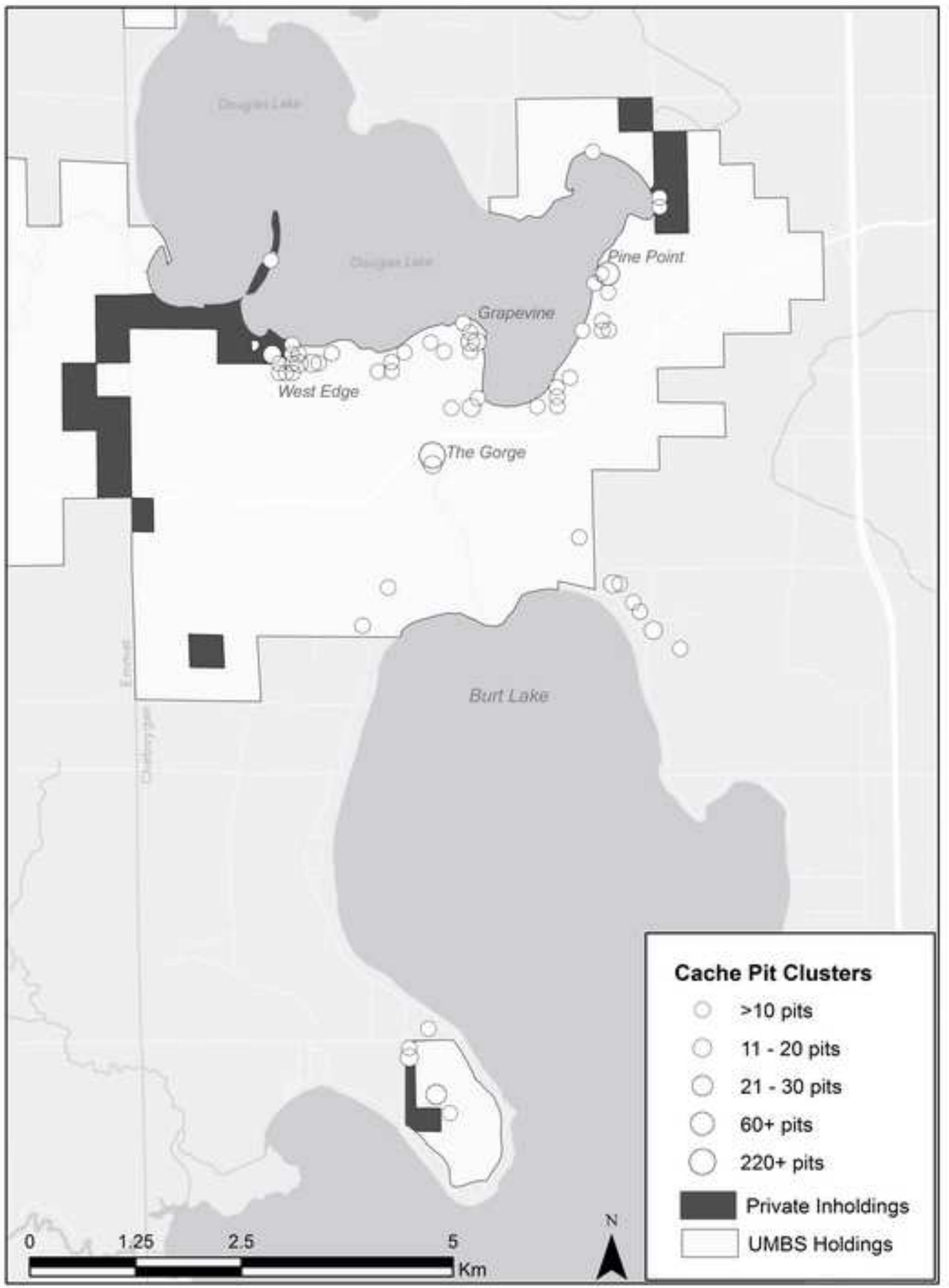




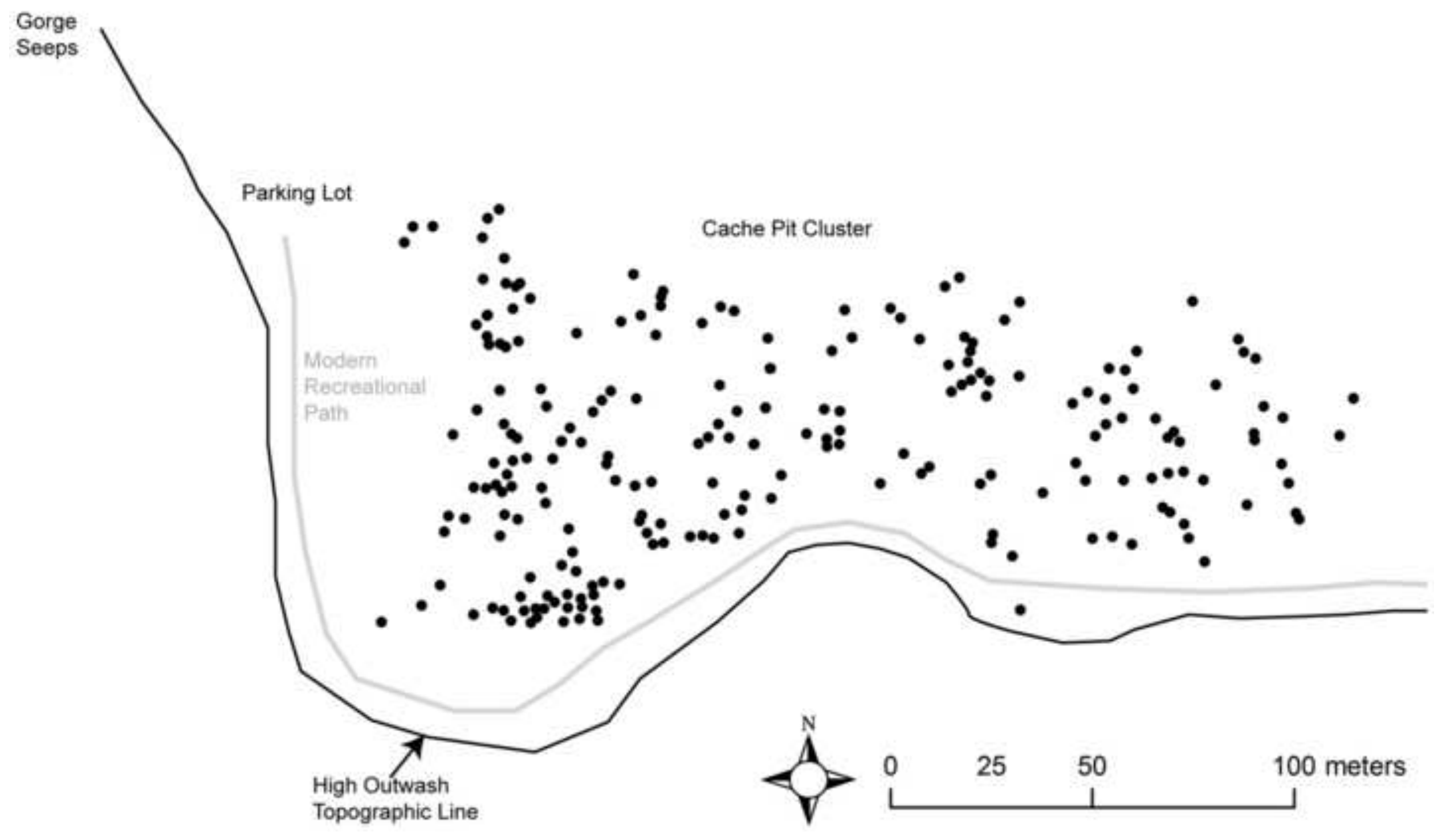




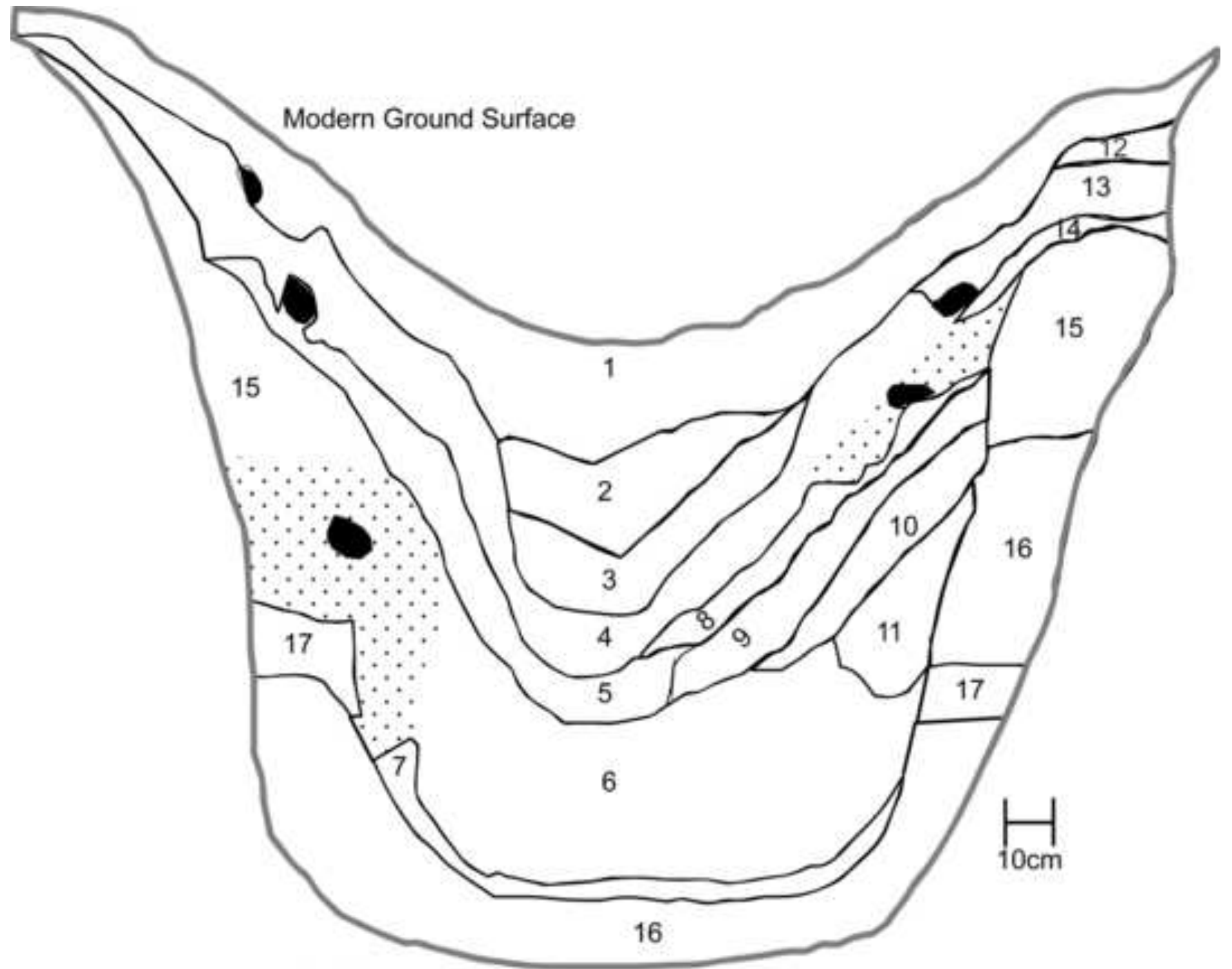

1. Modern Infill O/A Horizon (in pit)

2. Formed $E$ Horizon 10YR $6 / 3$ (in pit)

3. 10YR $2 / 2$ (in pit)

4. 10 YR $3 / 3$ (in pit)

5. 10 YR $3 / 2$ (in pit)

6. 10YR $3 / 3$ (in pit)

Root

(Note, dotted areas reflect where root damage was so extensive it obscured strata, including pit edge)

7. Dark Lens at base of pit 10YR $4 / 2$

8. Cut O/A Horizon 10YR2/2

9. Formative $E$ Horizon 10YR 5/3

10. 10YR $3 / 6$ (in pit)

11. 10YR 4/4 (in pit)

12. Upthrown B Horizon, pit construction 7.5YR $4 / 6$

13. Buried A Horizon, original surface at pit construction 10YR 2/2

14. Buried E Horizon (outside pit)

15. Sterile B Horizon (outside pit)

16. Sterile $C$ Horizon (outside pit)

17. Gravel Band in Sterile C Horizon cut by pit (outside pit) 


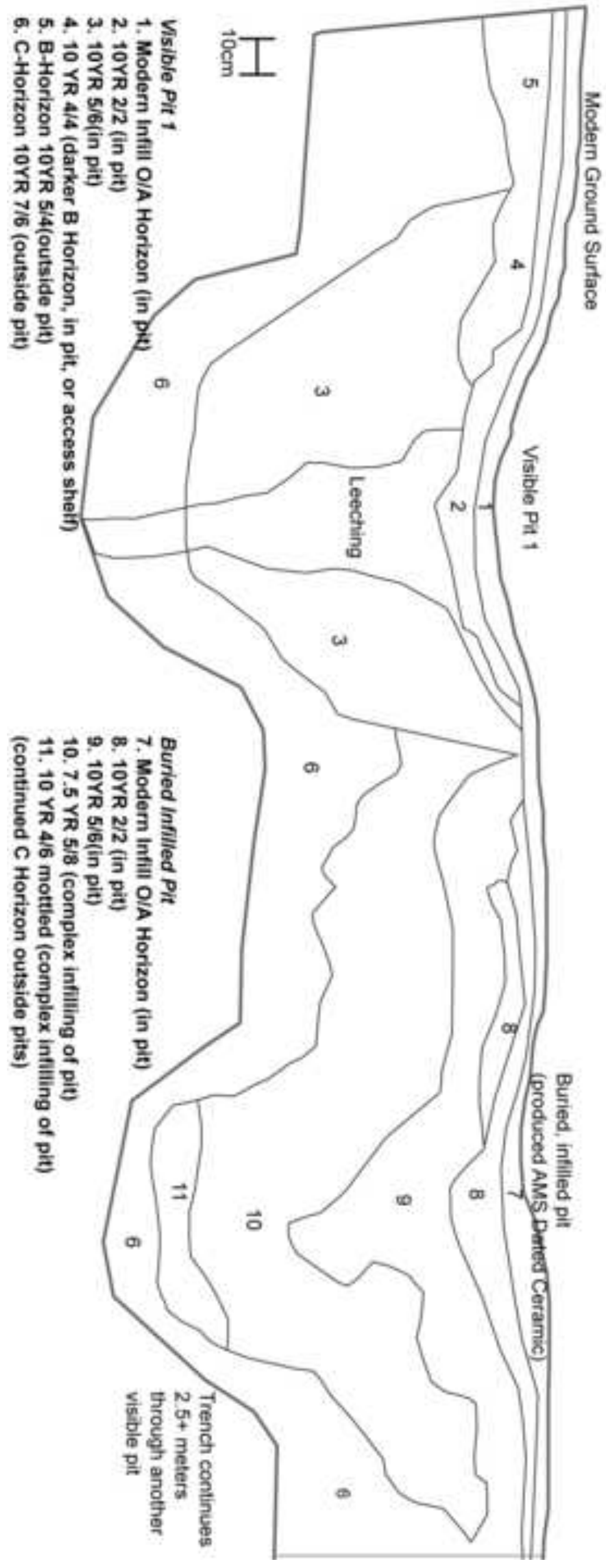




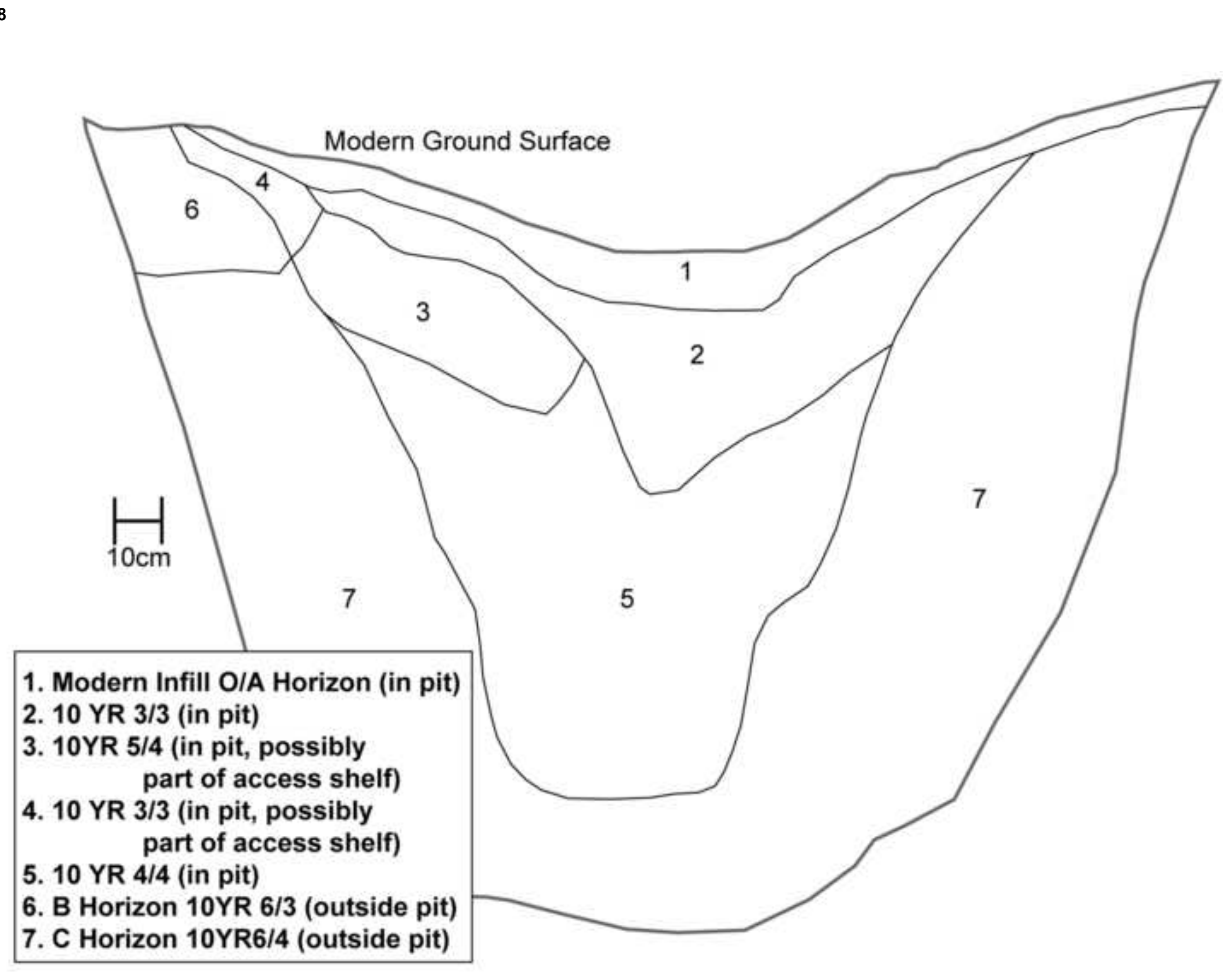

2. 10 YR $3 / 3$ (in pit)

3. 10YR 5/4 (in pit, possibly part of access shelf) part of access shelf)

5. 10 YR $4 / 4$ (in pit)

6. B Horizon 10YR $6 / 3$ (outside pit) 7. C Horizon 10YR6/4 (outside pit) 


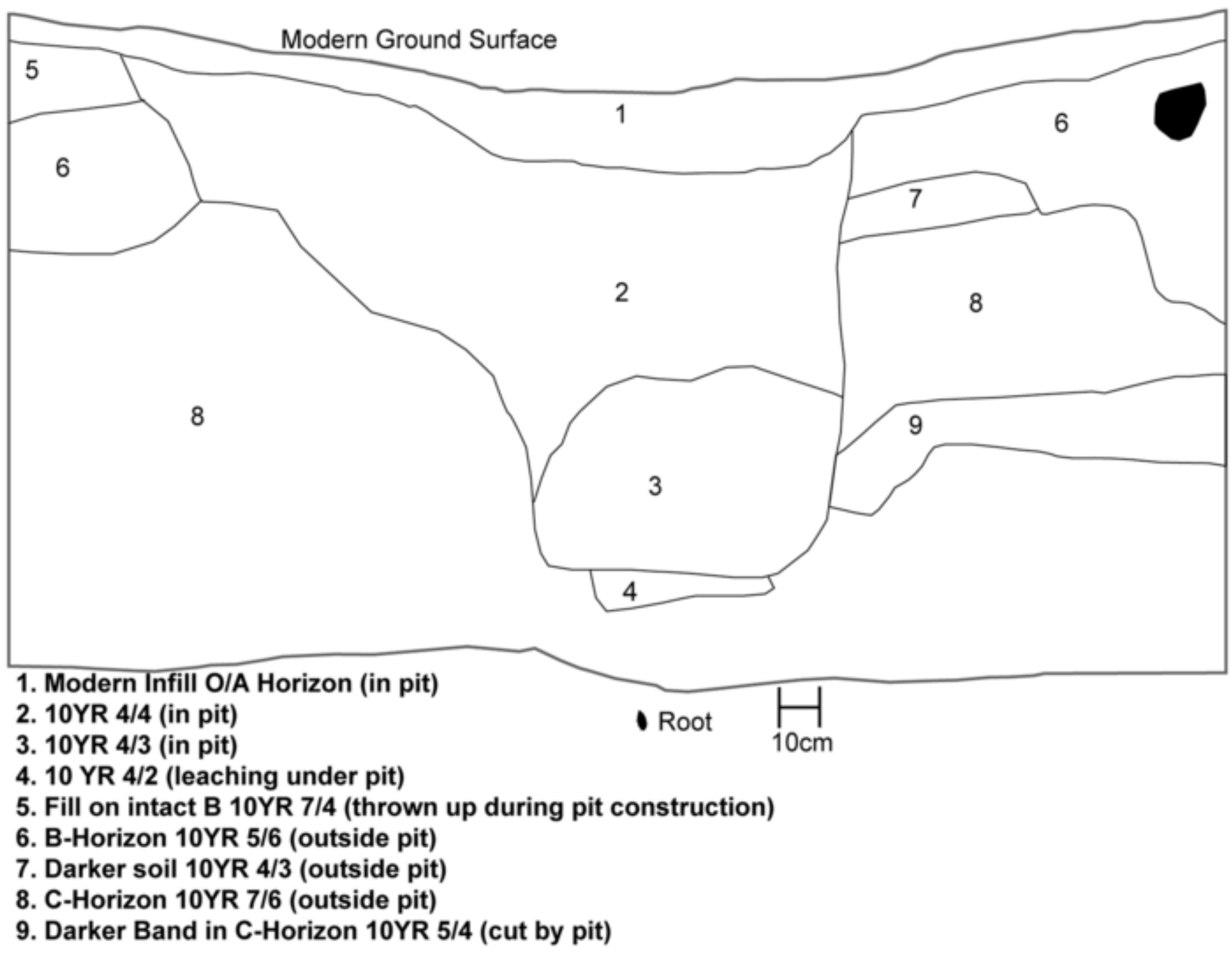

